Article

\title{
Long-Term Land Use Changes Driven by Urbanisation and Their Environmental Effects (Example of Trnava City, Slovakia)
}

\author{
Zita Izakovičová ${ }^{1}$, Peter Mederly ${ }^{2, *}$ (D) and František Petrovič ${ }^{2}$ \\ 1 Institute of Landscape Ecology, Slovak Academy of Sciences, 81438 Bratislava, Slovakia; \\ zita.izakovicova@savba.sk \\ 2 Department of Ecology and Environmental Sciences, Constantine the Philosopher University, \\ 94974 Nitra, Slovakia; pmederly@ukf.sk \\ * Correspondence: pmederly@ukf.sk; Tel.: +421-90-562-6151
}

Received: 6 June 2017; Accepted: 28 August 2017; Published: 1 September 2017

\begin{abstract}
Similar to other post-communist countries, Slovakia has undergone significant changes in the last decades-largely through transformation of central planning into a market economy. Unfortunately, this process has been associated with increasing pressure on surrounding ecosystems and their individual components. These changes are subject to various influences, e.g., socio-economic, political and environmental; in addition, urbanisation has also had great influence. This is typified by conversion of productive agricultural land and semi-natural ecosystems into built-up area accompanied by the negative ecological impacts of habitat deterioration and fragmentation. The rapidly changing consumption patterns of luxury living, transportation and leisure have increased the negative consequences on ecosystems and these compound the negative environmental trends. This paper evaluates land use changes in Trnava, which is one of the most rapidly developing cities in Slovakia. Evaluation covers 1838-2015, with explicit emphasis on transformation over the last 25-30 years. We present comparison with developments since 1990 in other cities in Slovakia, the Czech Republic and Germany and then discuss the main processes and environmental problems related to these changes, concentrating on the sustainability of current trends and appropriate planning and management responses.
\end{abstract}

Keywords: urbanisation; urban environment; urban sustainability; land use changes; Trnava city; environmental effects; global megatrends

\section{Introduction}

The European Environmental Agency has emphasised urbanisation as one of the major global megatrends with significant impact on world environmental quality [1]. Currently, up to $75 \%$ of the European population live in urbanized areas, and this is expected to increase to $80 \%$ by 2020 [2]. The concentration of people in cities promotes negative aspects associated with poverty, traffic problems and environmental degradation [3], and city development imposes qualitative changes focused on strengthening economic, administrative, and cultural-social functions. It also increases pressure on ecosystems and their individual components including natural resources and land use changes.

Landscape is a very dynamic system, with natural and social interconnected systems vastly affected by constant change [4]. Time and space are the two most important universal variables, where natural and human forces unite to form - and permanently change- the natural landscape into a cultural one, thus providing its unique character [5]. Urban landscapes reflect the predicaments arising from societal development because all social changes eventually influence changes in landscape 
structure and utilisation. While land use is determined by the attributes of natural components and comprises a specific proposition for anthropogenic landscape use and creates limits on its utilisation, its final use is determined by societal requirements, demands, abilities and overall land use possibilities. These components change over time due to altered human conditions, priorities, ownership and technology, so that goods previously valued as luxuries in the past are now considered essential. The change in society's demands and requirements impose cyclical changes in both the form and intensity of landscape use. Each development stage affects specific landscape structural features; where the land use changes reflect phases in government policy, socio-economic development and environmental change [6].

The European landscape has confronted many substantial socio-economic changes in the last 25 years and this is faithfully reflected in urban development. A specific driver of change in Central and Eastern European countries was the transformation from socialist centralisation to a market-driven economy. This was particularly manifested in spatial development by abolition of the state's privileged position in land-use decision-making and the introduction of privatisation and property restitution. These gradually led to changes in substantial real estate ownership and consequent functional land use. Post-socialist development also encouraged integration to a global politico-economic system with dynamics defined by neo-liberalism [7], increasing compatibility with the system and no longer restricting capital by national boundaries, thus encouraging increased regional competition to attract finance [8]. In addition to real-estate effects, the integrating Central European region has also become one of the main objectives of global capital investment through improved geographic and institutional proximity to Western investors [9,10]. This has seen an "offshoring" boom in many multinational corporation activities which are particularly advantaged by lower labour costs. This investment is quantitatively reflected in sequestration of natural resources and semi-natural ecosystems, and qualitatively by threatening both environmental quality and natural resources.

Although authors have investigated land use changes [11-17], environmental impacts have been less closely evaluated [18-26]. Tendencies in spatial and functional conversion of peri-urban areas have been recorded in many post-communist countries, with previously exclusive agricultural functions now complemented by progressive trade, administration, logistics and transport infrastructure. This has created a transition zone between city and countryside, where relatively separated urban sprawl, infrastructure and shopping-centre construction monopolise land consumption production and logistics operations on previous "green meadow". While urbanized area expansion at the expense of agricultural land is a common feature of post-communist change [6,27-32], problems of capturing natural and semi-natural ecosystems from urbanisation are also noted in other countries. A recently investigated phenomenon involves processes of suburbanisation or re-urbanisation [33,34]. Suburbanisation is a post-industrial phase increasing suburban zone area spatially separated from compact towns and cities [35], re-urbanisation signifies "gentrification" and revitalising inner city centres [36].

These related changes have affected Slovakia-twenty-five years of societal transformation has left an indelible mark on spatial organization. As in many countries, Slovak cities, as centres of concentration of human activities, present the most visible transformation [8]. The pressure from investors has increased in creating new residential, commercial services and shopping centres, logistic and industrial parks, and this is consequently reflected in land use change. The growth in built-up areas alters natural and semi-natural ecosystems and changes agricultural and forest-based land use. The accompanying loss of arable land, forests with increased unused agricultural areas and the elimination of vineyard and fruit orchard crops have changed Slovak suburban landscapes, thus ensuring their permanent transformation $[33,37,38]$.

The main aim of our research is to evaluate long-term land use changes in Trnava city and compare them with those in similar cities in Slovakia and adjacent countries. Concurrently, the accompanying factors and developmental trends typical for the last 25-30 years are discussed, and this especially covers impacts on the landscape, their components and environmental quality. While our results 
determine inefficiencies in land-use and planning and help identify negative urban development issues, most importantly, they help regulate urban planning according to the principles and criteria of sustainable development. It is hoped these determinations inspire further research in related issues.

\section{Materials and Methods}

Research methods focus on evaluating land use changes in the model area of Trnava over different time periods, their comparison to other related cities, and finally discussion of implications for the landscape, its components and the quality of the environment.

Primary sources for evaluating landscape changes are historical maps, statistics and text reports, and their interpretation by aerial photos, ortho-photomaps and historic maps from different sources is one of the most common methods. Current modern geo-information tools and methods (GIS) and accessibility to multi-data sources offer the greatest opportunities for retrospective landscape view [39-43]. In addition to traditional data from remote sensing (Landsat and SPOT), the GeoEye, QuickBird, WorldView, Ikonos, Sentinel and accessory aerial photograph methods provide very high resolution satellite data for tracking landscape changes.

Satellite and aerial imagery data give accurate information on spatial differentiation of landscape objects and their relationships, and their interpretation is more accurate than data from cadastral maps and statistics. Use of these inputs in assessing current land use change dynamics is especially important at the local level. Herein, periods with available data revealing historic milestones were chosen to evaluate the Trnava area, and our basic data sources include maps from the 2nd military survey in 1838 (Habsburg era), military maps of Czechoslovakia from 1955 (early socialism), aerial photographs from 1996 (post-socialism) and ortho-photomaps from 2015 (current era). These were readily sourced from the Slovak Central National Geoportal [44]).

Land use was also verified in the field in 1997 and 2015 [45,46]) and land use maps were processed using the ArcGis 9.3 information system (spatial accuracy 1:10,000), followed by spatial evaluation complemented by statistical data (as in Sections 3.1.1 and 3.1.2).

In evaluating the changes and trends in development of this town, the statistical data on Trnava and urban development documents provided the best source of information revealing changes and trends in township development $[45,47]$. Additional sectoral data from the Ministry of Environment and Ministry of Agriculture [48-50] and regional reports [51-53] gave background information on environmental quality and the intensity of anthropogenic impacts.

Assessment of these factors in Trnava was performed by conflict of interest [54] and GreenFrame methodology [55]. These methods evaluate the spatial overlay of positive and negative environmental factors, assessing their relationships and intensity on a qualitative scale. The positive factors include natural resources, hotspots of biodiversity, nature protected areas and all positive features considered under threat, while negative phenomena endangering environmental quality include natural stress factors such as water and wind erosion, landslides, seismic activity and geo-hazards. These latter anthropogenic factors are primarily induced by mineral extraction, industrial production, intensive agriculture and forestry, landfills and urbanisation and transport, while secondary factors include air, water and soil pollution, biotope and biodiversity endangerment and excessive noise and noxious odours [56,57].

The methodology evaluating landscape "conflict of interest" combines qualitative assessment of actual threats and threatening factors in the Trnava area. This involves classification of environmental problems in the following groups [58]: endangerments in natural resources, landscape spatial stability and human health. This approach approximates the concept of spatial mismatches evaluated for urban areas [59].

In contrast, the "GreenFrame method" evaluates landscape capacity for providing ecosystem services in the Trnava area [60]. This examines the positive and negative environmental factors selected for basic assessment input, comprising the 14 landscape features selected by local stakeholders as the most important contained in the 32-analytical-layer database. Final assessment comprised 
reclassification within the same range from 0 to 1 for intensity of occurrence, and factor effects in the following; weighting of theme importance from -3 for strong negative environment and ecosystem service (ES) provision effect to +3 for strong positive effect. This enables production of landscape capacity analytical maps for 10 ecosystem services and their combination in provisioning, regulating and cultural ES groups. This method therefore assesses the area's overall environmental quality (as in Section 3.1.3).

Comparison of Trnava with other cities assesses the changes in land use and their relationship to population development. Here, we supplement research by Haase et al. [59], which assessed the relationship between population and household numbers, to envisage actual living-space in 188 European cities in 1990, 2000 and 2006. We selected eight cities: two in Slovakia and three in both the Czech Republic and Germany for comparison with Trnava. The referenced [61-63] statistical resources provided population data for 1990 and 2012, and artificial surfaces; agricultural areas; forests, semi-natural areas, wetlands and water bodies land cover categories were derived from the Corine Land Cover spatial layers for the same years [64]. Similarly, extended areas in the eight cities supplied circles with $10 \mathrm{~km}$ diameter around the central city area. The results, comparisons and main relationships are presented in Section 3.2.

Trnava is one of the most important cities in Slovakia. It covers both a district and a regional centre situated in the western part of Slovakia, approximately $50 \mathrm{~km}$ from the Slovak capital Bratislava (Figure 1). The city's cadastral area is $72 \mathrm{~km}^{2}$, with 64,295 current population and density of 900 inhabitants per $\mathrm{km}^{2}$. Although Trnava is a small city in European context, it shares all the typical problems associated with urbanisation and associated processes. It is an industrial centre with a high level of foreign investment, with the presence of PSA Peugeot, Sachs, Johns Manville and Samsung, and it is the most important Slovak road and railway crossroad. Significant strengthening of the city's importance was proven during the political and social changes of the 1990s, and strong pressure from investors to build new industrial facilities and residential areas prevailed in the 1990s. This is exemplified by its important automotive and technology parks, logistics centres and transport infrastructure.

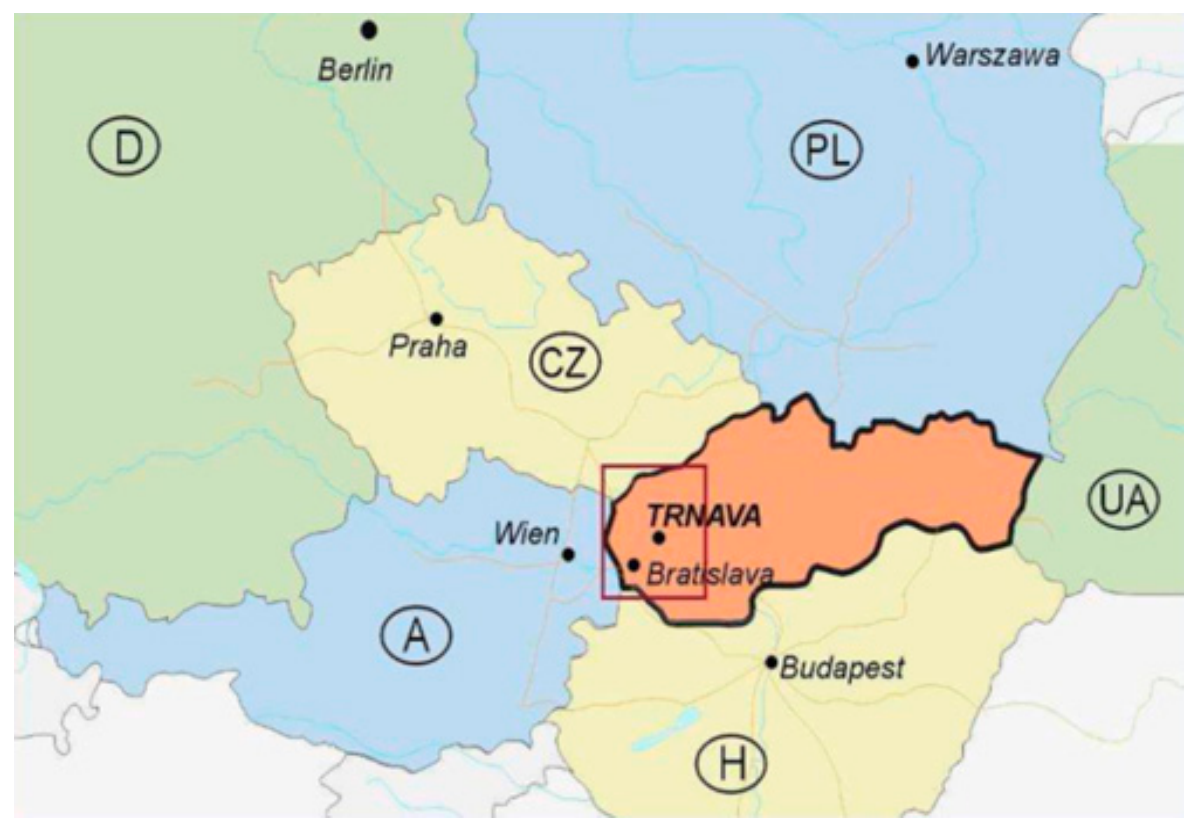

Figure 1. Location of Trnava city, Slovakia. Source [65].

Trnava city and its surroundings form part of Slovak lowland areas with low heterogeneity of natural landscape elements. Past and present intensive settlement and urbanisation has provided the 
Trnava area with high potential in human resources. The relatively flat surface of the loess lowland with some of the most fertile soils in Slovakia and a warm dry climate predetermined the highest priority of agricultural production; and agricultural land currently prevails in landscape structure occupying approximately $70 \%$ of the city's cadastral area. Arable land dominates this countryside, and, although cereals and forage reign, the percentage of energy crops is increasing. Livestock production is currently distributed among several farms, but this is gradually declining as farms change direction.

\section{Results}

Land use in the Trnava cadastral area was evaluated over four time periods-1838, 1955, 1996 and 2015. The landscape structure is briefly described from historical and actual maps and aerial photographs mainly from the National Geoportal of Slovakia [44] (Section 3.1.1), followed by comparison of land-use categories for evaluated time periods (Section 3.1.2), assessment of important environmental consequences (Section 3.1.3) and future outlook (Section 3.1.4). The second stage of the research compared current trends with similar cities in Slovakia, the Czech Republic and Germany (Section 3.2). The main factors and impacts of results and comparisons are described and discussed in Section 3.

\subsection{Historical Land Use Changes in the Trnava Area}

\subsubsection{Analyses of Historical Land Use}

1838

The historical land use of Trnava cadastral area in 1838 confirms the agricultural character of the landscape, mainly because of its suitable natural conditions, especially its good quality soils and favourable climate. In this period, arable land occupied more than three quarters of the area $(77.8 \%)$, and dominated in all parts except the urban area. The largest grassland plots lay along the Trnávka River flowing through the central part of the area, and also around streams such as Parná and Krupiansky potok. Meadows comprised the second most extensive element in the cadastre, with up to $12.2 \%$ of the area and deciduous forest covered almost 330 hectares $(4.5 \%)$ in the western Medziháje locality.

The settlement was mostly located in the central and southern parts of the cadastre, but together with the gardens, occupied only $2.2 \%$ of the area. The built-up area mostly comprised historical remnants, complemented by special and sacred buildings, monuments and sculptures. Church architecture and the city wall system ensured Trnava's historical significance.

Many companies focused on the food industry and Trnava was already one of the major industrial centres in Slovakia with a textile factory and one for silk fabric production. In addition, several water mills processed local agricultural products and small plots of clay and sand extraction were established close to the city.

Major roads linked the city and surrounding settlements, and Trnava's importance was emphasised by railway connection with the national capital-"Trnava to Bratislava" was the first such transit built in Slovakia. This promoted localisation and encouraged development of the many industrial facilities in this city.

\section{5}

Trnava land use in 1955 was marked by increasing industrialisation and the process of agricultural collectivization. Slovak industrialisation after the Second World War was reflected in the location of new food industries processing chocolate, malting, vinegar and starch, and the establishment of a sugar refinery and city brewery and distillery. Machinery, chemical, textile and construction factories were then established, and the city's first and largest industrial zone was created near the railway south 
of the city centre, with the industrial and technical complexes covering $2.3 \%$ of the area. The developed built-up areas were mostly at the expense of agricultural land and natural ecosystems.

Trnava's economic development demanded increased housing. Construction of family homes expanded and apartment buildings began to flourish, thus creating the first housing estates in the city. Housing areas and facilities expanded to $2.7 \%$ of the area and accompanying residential greenery in the gardens and parks covered $6 \%$ of the city. A recreational-relaxation zone with urban gardens and cottages was established in the Kamenný mlyn (mill) area close to the Trnava ponds, and several railway lines and added communication paths crossed the area, occupying over $4 \%$ of the cadastral area.

Agricultural collectivization initiated land parcel concentration, consolidation and creation of a mono-functional intensive agricultural landscape around the built-up centre. The remaining forests, non-forest woody vegetation, and meadows and pastures were transformed. Thus, the last remaining ecologically important areas were removed, and the entire lowland area became intensively used arable land with low ecological stability. Approximately $84 \%$ of the area became large-scale arable land, and forests and permanent landscape vegetation was reduced to $1.8 \%$ of the area, further confirming agricultural intensification in the area.

\section{7}

Growth of built-up areas at the expense of agricultural land was the most significant trend in land use change during the 1955-1997 socialist era. The rural population of Slovakia moved to towns to find employment opportunities and services. New industries, including machinery, chemical and furniture production flourished in Trnava, so that, by 1996, industrial, technical, and transport areas and facilities occupied $9.1 \%$ of the area; an increase of $2.7 \%$ since 1955 . New industrial areas were built, especially in the southern and southeastern parts of the city.

This process led to construction of new residential areas where housing, civic amenities and green areas covered $11.5 \%$ of the area; a $5 \%$ increase. Housing development in this period focused mainly on construction of spacious apartment houses, and these gradually migrated from the historical centre to the periphery of the city, thus creating large housing estates.

The high population concentration associated with industrial development also produced negative phenomena. The main features of socialist urbanisation involved significant suppression of human scale, gigantism, monotony, loss of construction aesthetic and artistic principles and an amorphic residential environment [66].

Arable land occupied most of the area until 1997, but this then fell below 75\%. Although there was 600 ha loss of agricultural land driven by expanded housing and industrial development in this 42-year period, the 3\% increase in grassland and residential green space was a positive outcome. In addition, while Trnava pond construction increased watered surfaces to $0.8 \%$, the insufficient amount of vegetation remained almost unchanged, with forest and landscape vegetation reduced to $1.8 \%$ of total Trnava area.

\section{5}

Current Trnava land use and evaluated changes are based on societal transformation and the economy, especially after 2000. The 1997-2015 period was significantly affected by Slovakia's admission to the European Union. The greatest changes were clearly economic, as the economy moved from a centrally-planned to market-oriented economy. This transformation also involved restitution and re-arrangement of ownership; initiating owner changes and subsequent alterations in property functional use. This was reflected mostly in the city centre where many residential buildings were converted to service facilities, resulting in higher city building density. This led to lifestyle changes, and the demand for quality housing increased pressure on the city's spatial development [52].

Changes in land use in the 1997-2015 period resemble those of previous years-the decline in agricultural land continued and built-up areas increased. While current agricultural land in the area is only $70.4 \%$, a decrease of up to $7.5 \%$ from 1997 , industrial, technical and transport facility areas rose by 
5 to $13.3 \%$ and housing and civic amenity area grew to 998.5 hectares- $-13.9 \%$ of the total area and a $22 \%$ increase in less than 20 years. Developmental trends since 1990 are obvious in the housing market. Demand increased, with larger homes in vogue for newly created residential areas. Houses in existing suburbs underwent reconstruction and combined with flat extensions they significantly increased density and anthropisation of the Trnava area. New housing and civic amenities construction is linked to natural and semi-natural ecosystem existence and this has induced significant pressure on productive soils in peripheral urban areas.

The flat terrain and large-scale arable land provide ideal space for large-scale construction, whether residential complexes and service areas, multifunctional buildings logistics centres or shopping malls, so the overall land appropriation for these functions was significant. The 2006 construction of the PSA Peugeot Citroën car company on 193 ha and several related companies in the southeastern part of the area are the most significant investments occurring in the recent past. Further landscape occupancy is associated with construction of new industrial and logistic areas on the city outskirts, construction of a new road network associated with PSA Peugeot, motorway junction and city bypass. Further land transformation has resulted from growth of existing industrial zones, company expansions and the Johns Manville and Sachs new production sites.

While arable land comprises $97.3 \%$ of agricultural area and dominates outside city limits, percentages of grasslands, currently $1.8 \%$, and permanent crops in orchards, vineyards and peri-urban gardens at $0.9 \%$ are continually decreasing. In addition, forests and landscape vegetation cover only $1.7 \%$ of the area and water elements even less at $0.7 \%$, so it is quite apparent that investor pressure continues to focus on appropriating agricultural area.

\subsubsection{Evaluation of Land Use Changes: 1838-2015}

The historical changes in the main land use categories in Trnava cadastral area are documented in Table 1 and Figures 2 and 3. These delineate the overall trend of urbanisation, highlighted by increased residential and technical land use, particularly at the expense of agricultural land. While residential and technical centres amounted to $12.4 \%$ in 1955 and agricultural land $85.2 \%$, these are currently $27.2 \%$ and $70.4 \%$, respectively. This translates to 1060 ha-14.8\% of Trnava cadastral area-increase in urbanized area over the last 60 years with corresponding 1062.4 ha loss of agricultural land.

Table 1. Land use category areas in Trnava cadastral area (1838-2015).

\begin{tabular}{lcccc}
\hline \multicolumn{1}{c}{ Land Use Categories } & $\mathbf{1 8 3 8}$ & $\mathbf{1 9 5 5}$ & $\mathbf{1 9 9 7}$ & $\mathbf{2 0 1 5}$ \\
\hline Residential area-housing, civic amenities & 88.2 & 195.8 & 355.8 & 407.5 \\
Residential area-gardens, urban green areas, open spaces & 68.0 & 233.0 & 463.4 & 591.0 \\
Production and technical areas, transport network & 101.3 & 461.2 & 648.7 & 950.9 \\
Urbanized landscape (total area, in ha) & 257.5 & 890.0 & 1467.9 & 1949.4 \\
Arable land & 5615.2 & 6078.5 & 5278.3 & 4901.0 \\
Grasslands-meadows, pastures & 830.6 & 13.0 & 173.0 & 89.8 \\
Permanent crops-vineyards, orchards, peri-urban gardens & 1.6 & 3.5 & 52.6 & 44.7 \\
Agricultural landscape (total area, in ha) & 6447.4 & 6095.0 & 5503.9 & 5035.5 \\
Forests and landscape vegetation & 440.2 & 128.9 & 126.6 & 119.8 \\
Water courses and bodies & 8.1 & 39.3 & 54.8 & 48.5 \\
Other use (total area, in ha) & 448.3 & 168.2 & 181.4 & 168.3 \\
Trnava cadastre area-total (in ha) & $\mathbf{7 1 5 3 . 2}$ & $\mathbf{7 1 5 3 . 2}$ & $\mathbf{7 1 5 3 . 2}$ & $\mathbf{7 1 5 3 . 2}$ \\
\hline
\end{tabular}

Figure 4 highlights the change in urbanised area compared to "open" landscape; reflected not only in agricultural land but also in forests, landscape vegetation, water surfaces and area population density. While urbanised areas have increased over time, from $3.6 \%$ of the area in 1838 to $12.4 \%$ in $1955,20.5 \%$ in 1997 and $27.2 \%$ in 2015, population density has declined from 45 inhabitants per ha in 1997 to 33 in 2015. The figure also illustrates expected urbanised area growth by 2035, despite the further decline in inhabitant numbers discussed in Section 3.1.4. 


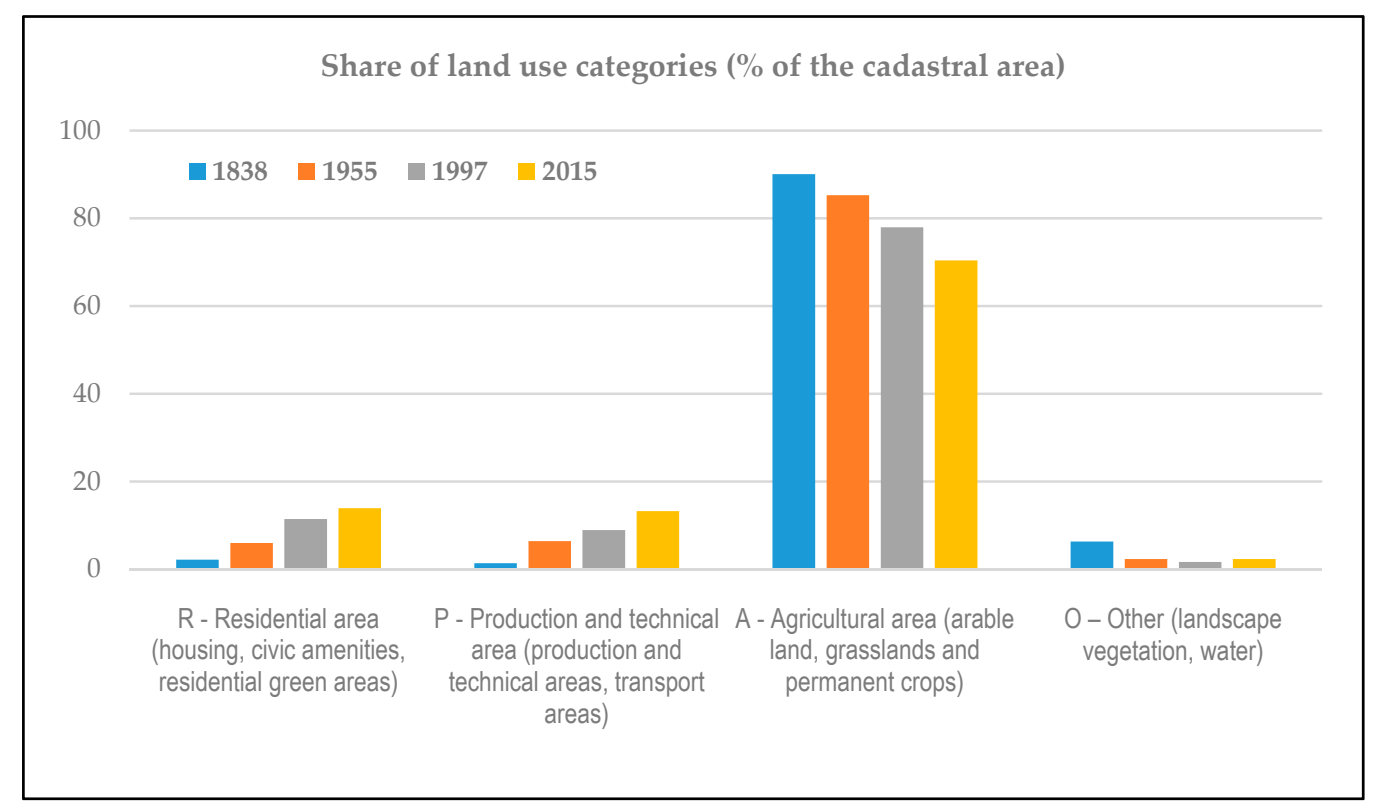

Figure 2. Land use categories in Trnava cadastral area (1838-2015).

Three basic trends in Trnava land use changes are identified in the comparison of historical maps:

- The growth in built-up areas is recorded gradually over the entire studied period. Major factors in this change since 1955 are industrial development, residential complex construction and consequent development of service facilities and transportation networks. Meanwhile, trends since 1990 centre on construction of large commercial and administrative centres. After Bratislava, Trnava is one of the regions with the greatest increase in built-up areas in Slovakia [38], as new industrial and commercial activities are located on regional and trans-regional axes as well as in the city centre.

- The gradual loss of arable land is linked to expanding city development where constant investment pressure converts agricultural land with the best quality soil in Slovakia into technical areas, with concomitant negative landscape effects. Construction of industrial and logistics facilities, transport networks, shopping centres and residential areas are the largest sites of land transformation in the area, and unfortunately, as in other sub-urbanized areas, these are at the expense of "green fields".

- $\quad$ The increasing density of built-up area in the inner-city further highlights that new home-unit construction in the city has usurped public greenery and urban gardens. Although green areas are increasingly appropriated for transport and parking networks, it cannot keep up with demand.

These main trends require evaluation in the wider context of social, economic and environmental consequences, which is confronted in the Discussion Section. 


\section{Historical land use development} in Trnava cadastral area
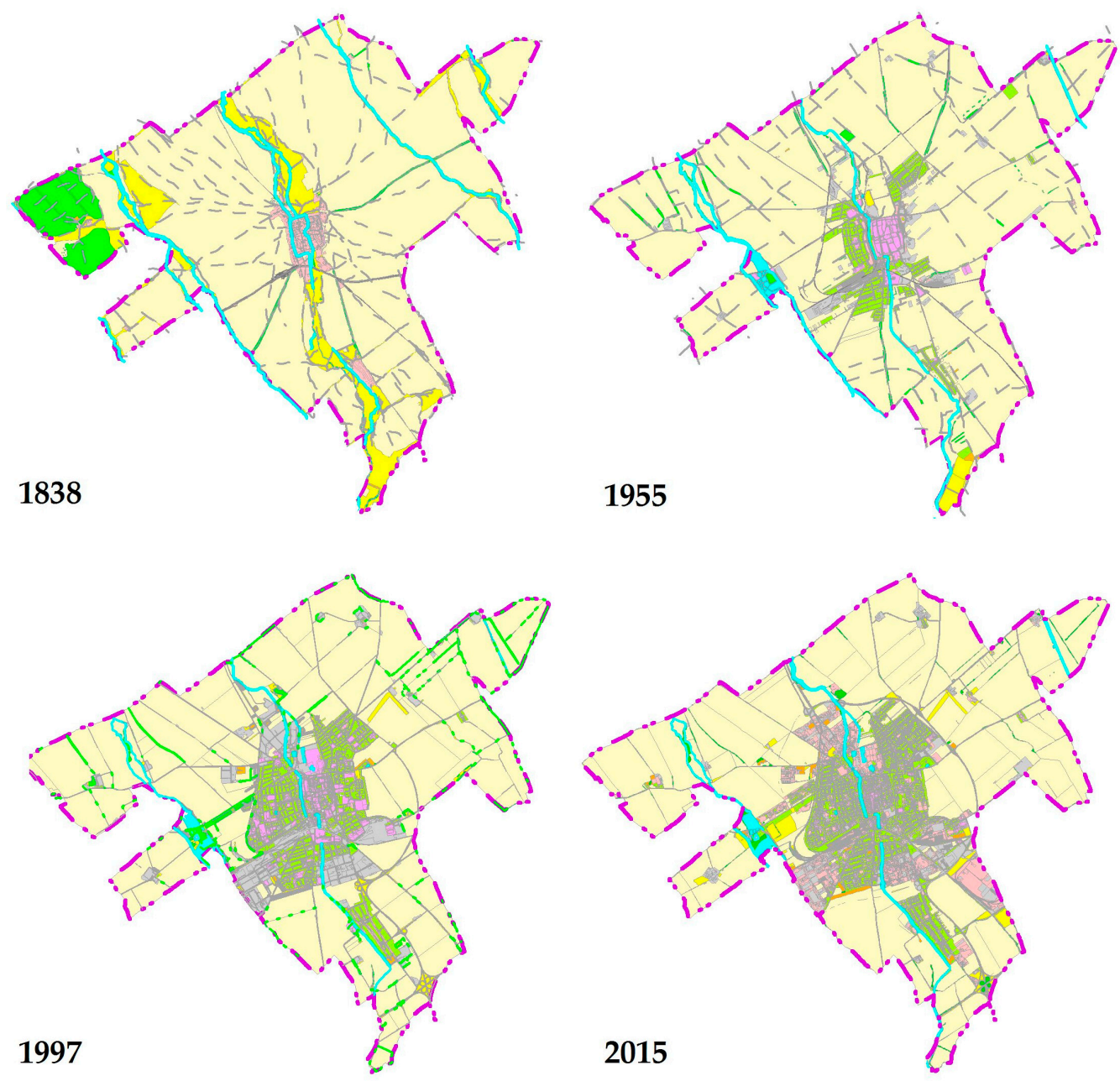

Main categories of land use

Urbanized landscape

residential area - housing

residential area - civic amenities

production and technical areas

transport network

green areas, open spaces

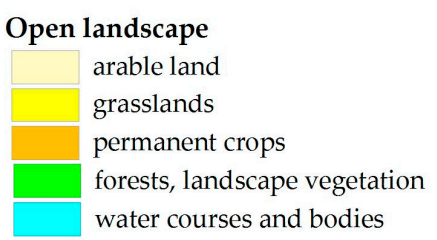

Trnava town - cadastral area border

Figure 3. Historical land use development in Trnava cadastral area. 


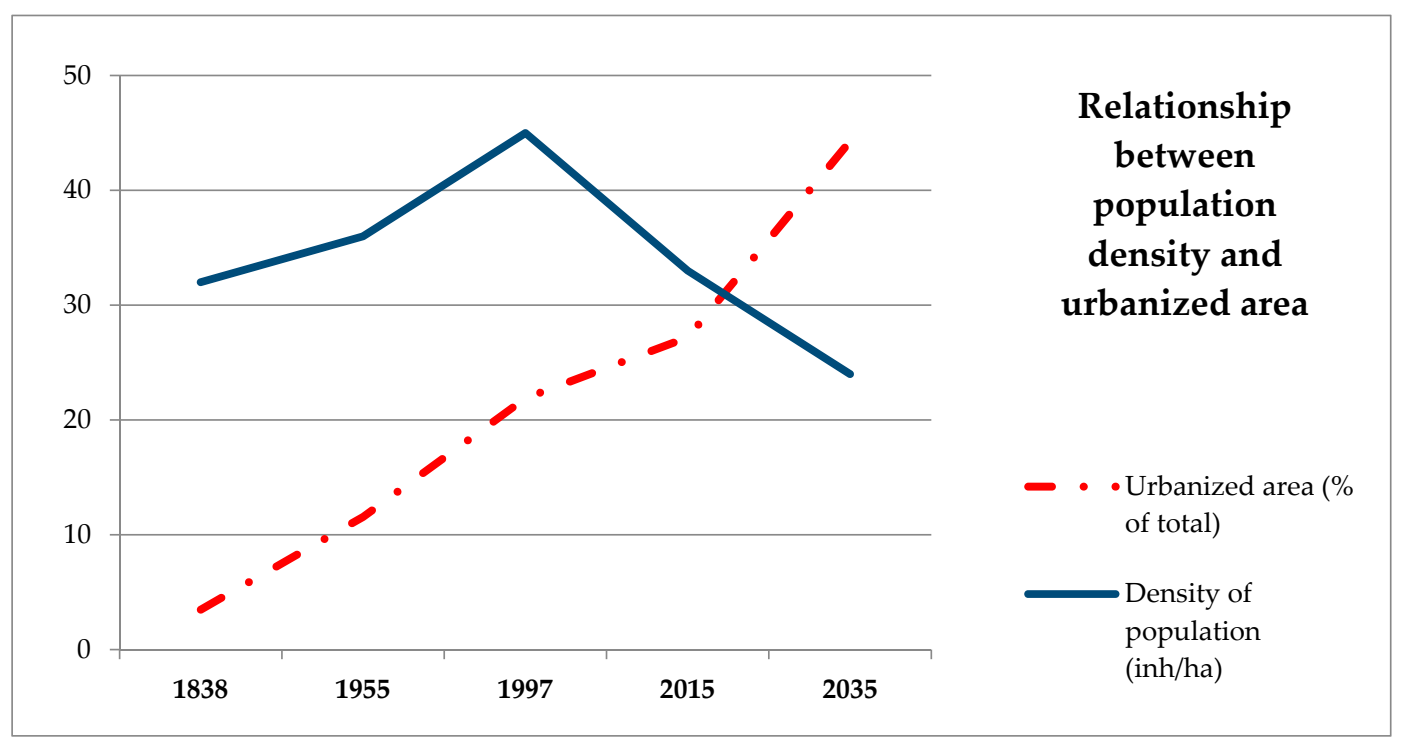

Figure 4. Relationship between population density and urbanised area in Trnava town.

\subsubsection{Environmental Quality in the Trnava Area over Time}

The state of the Trnava environment and its development in the region is based on the area's geographical location, its nature and landscape-ecological relationships, historical development and human activities. Historically, although negative anthropogenic effects on landscape soil and water were first observed in 19th century industrialisation [45], there is no relevant database for assessment of environmental component quality, nor improvements or increased damage.

The rapid industrialisation and intensive agriculture since 1950 has received insufficient ecological attention, with economic gains and population employment receiving highest priority. Many industrial plants burdened the environment, producing excessive emissions and discharging polluted water into watercourses; especially the Trnávka river. Pollutants have contaminated various environmental components and the overall environmental quality has deteriorated with inadequate monitoring and quality assessment. Precise objective assessment of ecological and environmental impacts from industrial development is impossible because little information on the state of the environment had been published; or perhaps even hidden [67].

Environmental consequences of current development are also obvious. The most controversial issue is the problem of "green field" investments. This covers occupancy of high quality soils by industrial centres, housing and civic amenities. (1st-2nd soil production class on nine-degree Slovak scale). Concurrently, there is also the existence of "brownfields", such as abandoned sugar refinery and brewery city areas.

Although Trnava has significant reduction in emissions and improved air quality since 1990, negative impacts of industrial production on the landscape, its components and the environment persist. A total of 184 large and medium air pollution sources was recorded in the city area [52]. While emissions of arsenic, vanadium, chlorine, tetrachloroethylene and alkyl alcohols have increasing trend since 2000, these are small amounts compared to the main oxides of sulphur, nitrogen, carbon and particulate matter pollutants from industrial plants. Road traffic is also guilty of environmental damage, emitting $\mathrm{CO}, \mathrm{NO}_{\mathrm{x}}$, volatile organic compounds (VOCs) and particulate matter $\left(\mathrm{PM}_{10}\right)$ air pollution.

Surface and groundwater quality also causes problems. Although water quality has improved since 2000, some pollutants remain over the limit. Trnávka River is currently one of the most polluted water course in Slovakia from industrial plants and low water discharge. Nitrite nitrogen $\left(\mathrm{N}-\mathrm{NO}_{2}\right)$ and ammonium nitrogen $\left(\mathrm{N}-\mathrm{NH}_{4}\right)$ exceed water quality values the most, and increasing levels 
have been recorded in the biochemical oxygene demand $\left(\mathrm{BOD}_{5}\right)$ and chemical oxygene demand $\left(\mathrm{COD}_{\mathrm{Cr}}\right)$ indicators [52].

Current urbanisation and increasing traffic congestion impose the following negative impacts: occupation of green areas, pollutant production and increased noise and dust [68-72].

Collectivised agriculture has also left negative traces on the landscape, as unified land parcels eliminated non-forest vegetation and the green areas created intensively used arable land with low ecological stability in the town's surroundings. Extraneous soil substances and groundwater substances also prevail due to excessive use of fertilizers and livestock farming, and soils in the wider area have slight nickel, cadmium, copper, zinc and fluorine contamination above reference values [48].

Increased concentrations of iron, manganese and nitrate were also identified in the groundwater [52], and mono-functionality of the agricultural landscape has exposed the landscape to water and wind erosion and soil compaction. Of these, wind erosion is most significant with approximately 1000 hectares of agricultural land at risk, and the swirling dust unfortunately creates health problems [52].

From a long-term perspective, there is a significant shortage of recreational and leisure areas in Trnava and its surroundings because the urbanised area is closely surrounded by intensive agricultural landscape and unfavourable natural conditions. Lack of public green areas, such as parks and forest-parks, is also obvious, with existing areas scattered across the city and serving only for daytime recreation and leisure. Trnava certainly does not have sufficient public greenery to meet the $75 \mathrm{~m}^{2}$ per capita standard [73] — the deficit is estimated at $35 \mathrm{~m}^{2}$ per capita, or 226 ha [45]. A relatively large proportion of green areas comprise individual allotments and urban gardens inaccessible to the public, under constant pressure from investors and gradually consumed for housing construction.

In addition, the most important recreational area "Kamenný mlyn" is situated close to the Trnava ponds nature-protection-area with its significant aquatic and wetland biotope and nesting site for important water birds species. Since recreational possibilities in Trnava are now limited [74], it is paramount to build new close recreational and leisure zones for the city's inhabitants rather than have possible sites appropriated by construction and industry.

Classification of environmental problems for the Trnava area based on "conflict of interest" methodology [54] poses these main environmental issues [58]:

- Endangerment of natural resources: agricultural land appropriation, water and wind erosion, air pollution, water pollution, and soil contamination.

- Endangerment of landscape spatial stability: decrease in forests and other biotope areas, intensive agriculture, and built-up area sprawl.

- Endangerment of human health: effects of air and water pollution, and soil contamination, plus those of intensive traffic and public green areas deficit.

Meanwhile, the "GreenFrame" method evaluates landscape capacity for ecosystem services provision [55], and the following main environmental factors were determined by stakeholders' perception for the Trnava area's future [60]:

- Main positive environmental features: groundwater resources, productive agricultural soils, game reserves, important biotopes for protected and endangered species, nature protected areas, bio-centres and bio-corridors, important urban green areas and cultural and historical landscape features including the mosaic of vineyards and orchards.

- Main negative environmental features: areas endangered by erosion and flooding, areas under intensive anthropogenic pressure (industry, traffic, recreation), environmental loads (landfills and contaminated areas), areas with air and water pollution and soil contamination, and finally areas affected by invasive species and allergens.

The overall environmental regionalisation of the area is based on the spatial overlay of the individual factors which positively or negatively influence landscape quality (Figure 5). It is expressed 
as a qualitative assessment on a "dimensionless" relative scale of very high to very low degree of quality. The most significant cumulative positive factors for high environmental quality are related to the occurrence or proximity of water bodies, streams and water resources, significant landscape habitats and urban green areas. In contrast, low and very low environmental quality is typical for production zones and technical areas, densely populated urban areas and significant traffic corridors where negative factors accumulate. Spatial projection provides obvious agricultural landscape zoning. The intensity of negative factors decrease with distance from the central city and production areas, and environmental quality is slightly improved.

\section{Overall environmental quality of Trnava area}

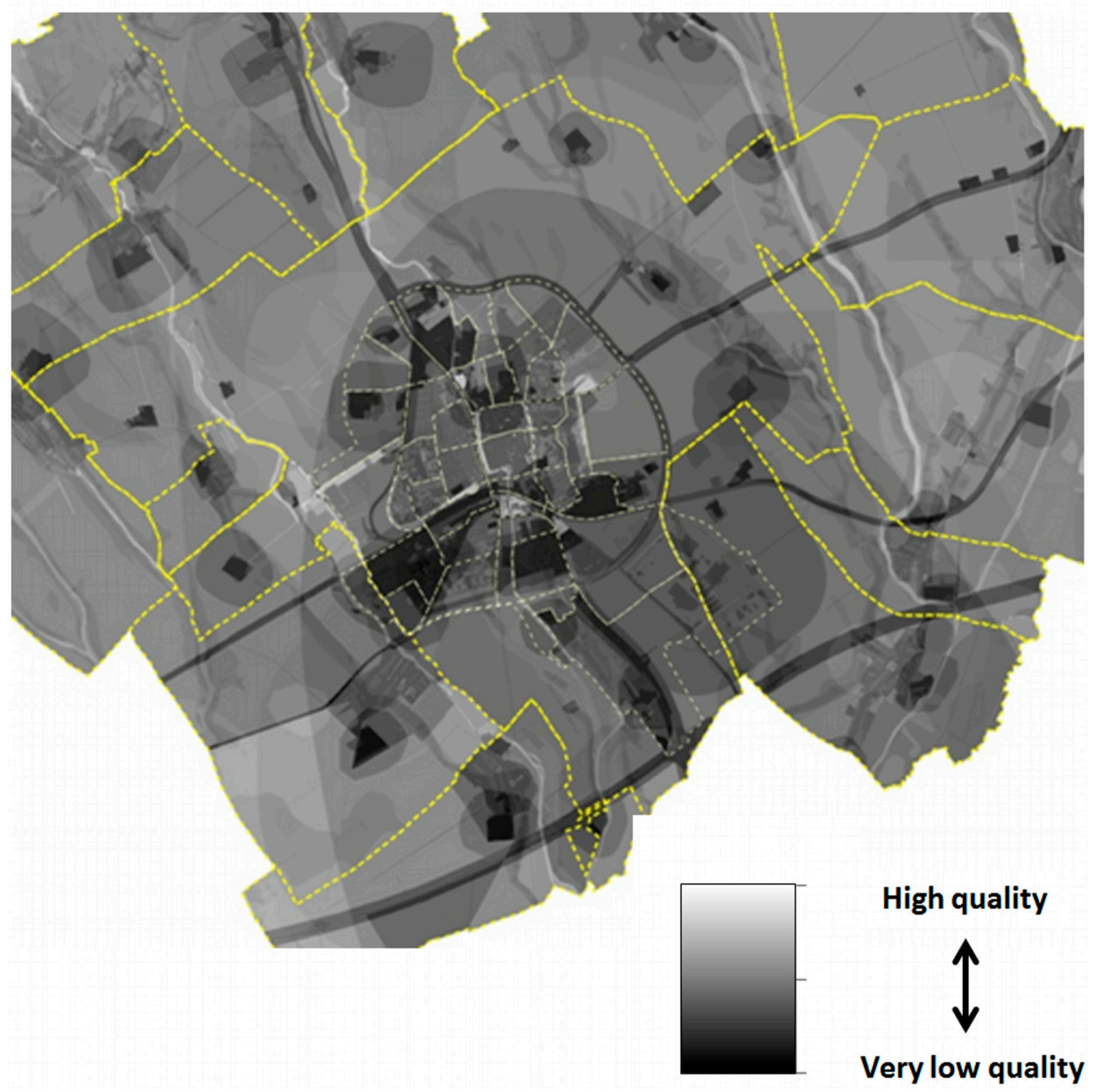

Figure 5. Overall environmental quality of Trnava area.

\subsubsection{The Outlook for Future Spatial Development}

Trnava must respond to all current challenges of spatial development trends and environmental issues by appropriate planning and management. A territorial urban plan was approved in 2009 [47], and several amendments have been adopted which provide authorities with appropriate guidance for management of the city's spatial development. Trnava has also produced a well-processed strategic environmental document with inclusion of the principles and criteria for sustainable development [45]. However, solving problems in implementing planning documents in actual practice is crucial; and this is further explored in the discussion section.

The approved municipal urban plan [47] provides for continued growth of Trnava's urbanised area to more than 1200 ha (44.3\%) by 2035; an increase of almost 70 ha per year. Although the number of inhabitants has decreased by 5000 since 1997 through migration to suburban municipalities and 
there has been continuous incremental decrease since 2000, Figure 3 confirms that the city is spatially growing. This also indicates a decline in urbanized area population density; a typical feature of current sub-urbanisation processes [34] and described as "urban shrinkage" [75].

Although this official decline in inhabitants exists, the actual number of "every-day" people in Trnava is growing. This includes university students and people working in the tertiary sector and new production facilities, so appropriate services must be planned for this increase [47]. It also requires a broader scale of social services, covering secondary and higher education, health, culture, commerce and official administration. While most commercial service development is planned for the city outskirts, it should especially focus on introduction of multifunctional business and service hyper-centres with regional character.

Large spatial reserves are mainly allocated to development of new housing construction. By 2025, construction is planned for approximately 10,500 flats. Based on the size and structure of individual modern-day families, this figure is much greater than projected population growth [76]. To ensure future prosperity, intensive city development requires considerable investment in technical service equipment and transport systems.

A proposal for the built-up area environment is on the agenda. This intends to increase the extent of public green areas by 250 ha by 2035 and thus provide the required percentage of functional green infrastructure. This especially refers to park and forest park greenery which is currently insufficient. A positive feature is that the planning document proposes increasing environmental quality and ecological stability, both within the city and in the "open" landscape. This formed part of the ecological network document [45] included in an approved urban plan for an extensive system of landscape bio-centres, bio-corridors and other green areas. Implementation involves gradually increasing and maintaining landscape green elements from the current 120 ha to over 650 ha (12\% of the open landscape). While this will be linked to the great extent of agricultural area land-appropriation, the current deficit of ecologically positive elements in the countryside would be solved and the overall quality of the area's environment would be significantly improved. However, this heavily depends on whether these proposals will actually be implemented, because Trnava's current urban development practice tends to reduce green areas rather than encourage their spread [77].

\subsection{Comparison the Trnava Area with Other Similar Cities}

Results of evaluation of historical land use changes for Trnava city were presented in the previous section. Their main factors and environmental consequences are also outlined, especially in the post-socialist period after 1990. Comparisons with cities of similar size in different territories and different geographic conditions are most important in verifying the wider validity of these findings. Here, we have chosen other cities in Slovakia (Nitra and Banská Bystrica), the Czech Republic (Olomouc, Liberec, and Ústí nad Labem) and Germany (the former territory of the German Democratic Republic-Frankfurt/Oder, Cottbus, and Schwerin). Their basic characteristics are shown in Table 2, and, in addition to the main information sources from Corine Land Cover maps [64] and European and national statistics [61-63], we also enlarge on the results of Haase et al. [59,78] and local studies of the compared cities [79-85].

We focused on two main issues:

- comparison of changes in the main land use categories in the compared cities for 1990 and 2012; and

- relationships between population change, living area size and resultant population density over a given period. 
Table 2. Basic information on compared cities.

\begin{tabular}{|c|c|c|c|}
\hline City, Country & $\begin{array}{l}\text { Population } \\
\text { (1 January 2016) }\end{array}$ & Geographical Characteristics & Brief Description \\
\hline Trnava, Slovakia & 64,439 & $\begin{array}{l}\text { Lowland landscape-loess hilly-land of } \\
\text { Podunajská lowland, very fertile soils }\end{array}$ & $\begin{array}{l}\text { NUTS3 regional centre (SK021 Trnavský } \\
\text { kraj). Compact city with significant } \\
\text { industry, traffic junction. Extensive } \\
\text { investments after r. 1990-automotive, } \\
\text { logistics. Surroundings—-the dominance of } \\
\text { intensive agriculture. }\end{array}$ \\
\hline Nitra, Slovakia & 80,130 & $\begin{array}{l}\text { Border area of Podunajská lowland and } \\
\text { Tríbeč hills-3 basic landscape types: river } \\
\text { alluvium, loess hilly-land, lower mountain of } \\
\text { Western Carpathians }\end{array}$ & $\begin{array}{l}\text { NUTS3 regional centre (SK023 Nitriansky } \\
\text { kraj). Less compact city, industry in } \\
\text { peripheral areas. Extensive investment at } \\
\text { present (automotive). } \\
\text { Surroundings-intensive agriculture, } \\
\text { marginal parts of area-forest and vineyards. }\end{array}$ \\
\hline $\begin{array}{l}\text { Banská Bystrica, } \\
\text { Slovakia }\end{array}$ & 76,988 & $\begin{array}{l}\text { Border area of Zvolen basin and hig } \\
\text { mountains of Carpathians (Nízke Tatry, } \\
\text { Vel'ká Fatra, Kremnické vrchy) }\end{array}$ & $\begin{array}{l}\text { NUTS3 regional centre (SK032 } \\
\text { Banskobystrický kraj). Historical city with } \\
\text { a compact centre in the valley and a number } \\
\text { of suburban areas. Industry and logistics } \\
\text { are moderately represented. Surrounding } \\
\text { areas cover mostly forests and grasslands. }\end{array}$ \\
\hline $\begin{array}{l}\text { Olomouc, Czech } \\
\text { Republic }\end{array}$ & 100,154 & $\begin{array}{l}\text { Lowland landscape-river alluvium of } \\
\text { Morava river and hilly-land of basin } \\
\text { Hornomoravský úval }\end{array}$ & $\begin{array}{l}\text { NUTS3 regional centre (CZ071 Olomoucký } \\
\text { kraj). Historical compact city with } \\
\text { industrial suburbs and new investments. } \\
\text { Surroundings-the dominance of } \\
\text { intensive agriculture. }\end{array}$ \\
\hline $\begin{array}{l}\text { Liberec, } \\
\text { Czech Republic }\end{array}$ & 103,288 & $\begin{array}{l}\text { Undulate landscape of Žitava mountain } \\
\text { basin, contact with middle mountian ranges } \\
\text { Jizerské hory, Ještěd }\end{array}$ & $\begin{array}{l}\text { NUTS3 regional centre (CZ051 Liberecký } \\
\text { kraj). Compact historical city, the old centre } \\
\text { of the textile industry. New industrial and } \\
\text { commercial areas, surrounded by a various } \\
\text { land-use structure. }\end{array}$ \\
\hline $\begin{array}{l}\text { Ústí nad Labem, } \\
\text { Czech Republic }\end{array}$ & 93,248 & $\begin{array}{l}\text { Dissected intra-mountain landscape-river } \\
\text { Labe valley, slopes of České středohoří } \\
\text { mountains, partly hilly-land of Mostecká } \\
\text { panva basin }\end{array}$ & $\begin{array}{l}\text { NUTS3 regional centre (CZ042 Ústecký kraj). } \\
\text { Industrial and transport centre in the } \\
\text { outskirts of a brown-coal mining area. After r. } \\
1990 \text { stagnation, later recovery and } \\
\text { regeneration of the city. In the vicinity of the } \\
\text { city—diverse land use. }\end{array}$ \\
\hline $\begin{array}{l}\text { Frankfurt (Oder), } \\
\text { Germany }\end{array}$ & 58,377 & $\begin{array}{l}\text { Lowland landscape of the Odra river, part of } \\
\text { glacier-formed basin (Berliner } \\
\text { Urstromtal)—undulate landscape with high } \\
\text { share of wetlands }\end{array}$ & $\begin{array}{l}\text { NUTS3 regional centre (D403 Frankfurt } \\
\text { (Oder), Kreisfreie Stadt). Historical city, } \\
\text { originally developed along with the current } \\
\text { Polish city of Slubice, with which renewed } \\
\text { intensive linkages have now been } \\
\text { established. In recent years, industrial and } \\
\text { commercial sites are being constructed. } \\
\text { Arable land predominates in the city's } \\
\text { outskirts, but there are also larger areas of } \\
\text { grasslands, forests and water areas. }\end{array}$ \\
\hline $\begin{array}{l}\text { Cottbus, } \\
\text { Germany }\end{array}$ & 99,519 & $\begin{array}{l}\text { Basin-landscape lowland in the river Spree } \\
\text { valley, partly glacier-formed moraine }\end{array}$ & $\begin{array}{l}\text { NUTS3 regional centre (D402 Cottbus, } \\
\text { Kreisfreie Stadt). An industrial centre of the } \\
\text { south Brandenburg region. The most } \\
\text { important coal and energy supplier in the } \\
\text { former GDR-after the fall of the mining in } \\
\text { 1990s, there was a profound structural } \\
\text { change in the city and region. In the vicinity, } \\
\text { a significant representation of forests and } \\
\text { former coal mining areas; the structure of } \\
\text { agricultural landscape is variable. }\end{array}$ \\
\hline $\begin{array}{l}\text { Schwerin, } \\
\text { Germany }\end{array}$ & 96,800 & $\begin{array}{l}\text { Lowland landscape of glacier-formed basin, } \\
\text { high share of water bodies (Schwerin See) }\end{array}$ & $\begin{array}{l}\text { NUTS3 regional centre (D804 Schwerin, } \\
\text { Kreisfreie Stadt). Second largest city of the } \\
\text { Mecklenburg-Vorpommern, historical } \\
\text { centre. In the past, the territory was typical } \\
\text { by agricultural production and the food } \\
\text { industry. Nowadays with focus on services } \\
\text { and tourism. The surrounding landscape is } \\
\text { very varied with the prevalence of water } \\
\text { areas and the even distribution of forests, } \\
\text { arable land and grasslands. }\end{array}$ \\
\hline
\end{tabular}




\subsubsection{The Main Categories of the Land Cover Classes in 1990 and 2012 and Their Changes}

The main Corine land cover (CLC) class areas in 1990 and 2012 and their changes for the compared cities are presented in Table 3 and Figure 6. The results highlight the same trend in all cities; an increase in built-up area at the expense of agricultural land. While Trnava is a typical example, this common trend is most pronounced in Frankfurt/Oder, Cottbus, Liberec and Nitra cities. The growth of built-up areas (Class 1 in CLC) was documented in the range of 2.1-8.4\%-an average of 5.1\%; 398 ha; and 18 ha per year. The most significant increases were recorded in Frankfurt/Oder and Trnava, with average 30 and 26 ha built-up areas, respectively.

Table 3. Basic land cover classes area for 1990 and 2012 in selected areas of compared cities.

\begin{tabular}{|c|c|c|c|c|c|c|c|}
\hline \multirow[b]{2}{*}{ City } & \multirow[b]{2}{*}{ Year } & \multicolumn{3}{|c|}{ Aera in ha } & \multicolumn{3}{|c|}{$\%$ of Total Area } \\
\hline & & Class 1 & Class 2 & $\begin{array}{c}\text { Class } \\
3-5\end{array}$ & $\begin{array}{c}\text { Class } \\
1\end{array}$ & $\begin{array}{c}\text { Class } \\
2\end{array}$ & $\begin{array}{c}\text { Class } \\
3-5\end{array}$ \\
\hline \multirow{2}{*}{ Trnava, SK } & 1990 & 1807.0 & 5963.1 & 44.2 & 23.1 & 76.3 & 0.6 \\
\hline & 2012 & 2380.3 & 5389.8 & 44.2 & 30.5 & 69.0 & 0.6 \\
\hline \multirow{2}{*}{ Nitra, SK } & 1990 & 2783.2 & 4231.9 & 799.4 & 35.6 & 54.2 & 10.2 \\
\hline & 2012 & 3236.4 & 3626.9 & 951.2 & 41.4 & 46.4 & 12.2 \\
\hline \multirow{2}{*}{ Banská Bystrica, SK } & 1990 & 1970.7 & 3045.3 & 2799.3 & 25.2 & 39.0 & 35.8 \\
\hline & 2012 & 2203.3 & 2483.8 & 3128.2 & 28.2 & 31.8 & 40.0 \\
\hline \multirow{2}{*}{ Olomouc, CZ } & 1990 & 2755.8 & 4856.0 & 203.0 & 35.3 & 62.1 & 2.6 \\
\hline & 2012 & 2963.2 & 4629.5 & 222.2 & 37.9 & 59.2 & 2.8 \\
\hline \multirow{2}{*}{ Liberec, CZ } & 1990 & 2870.5 & 2952.7 & 1989.8 & 36.7 & 37.8 & 25.5 \\
\hline & 2012 & 3375.4 & 2443.7 & 1994.0 & 43.2 & 31.3 & 25.5 \\
\hline \multirow{2}{*}{ Ústí nad Labem, CZ } & 1990 & 2457.8 & 3071.9 & 2284.8 & 31.5 & 39.3 & 29.2 \\
\hline & 2012 & 2619.2 & 2957.7 & 2237.7 & 33.5 & 37.8 & 28.6 \\
\hline \multirow{2}{*}{ Frankfurt (Oder), D } & 1990 & 2370.1 & 3950.5 & 1494.1 & 30.3 & 50.6 & 19.1 \\
\hline & 2012 & 3029.6 & 2814.1 & 1971.0 & 38.8 & 36.0 & 25.2 \\
\hline \multirow{2}{*}{ Cottbus, D } & 1990 & 4109.0 & 2397.3 & 1309.3 & 52.6 & 30.7 & 16.8 \\
\hline & 2012 & 4556.4 & 1682.2 & 1577.0 & 58.3 & 21.5 & 20.2 \\
\hline \multirow{2}{*}{ Schwerin, D } & 1990 & 2458.1 & 1892.2 & 3465.5 & 31.5 & 24.2 & 44.3 \\
\hline & 2012 & 2797.8 & 1729.4 & 3288.6 & 35.8 & 22.1 & 42.1 \\
\hline
\end{tabular}

Source of data: Corine Land Cover [64], Class 1, Built-up areas; Class 2, Agricultural land; Classes 3-5, Forests, permanent vegetation, wetlands and water elements, respectively.

The decline in agricultural land (CLC class 2) in the compared cities averages 6.5\%, 512 ha for the whole period and 23.3 ha per year. The most significant decline was recorded in the German cities of Frankfurt/Oder (a total of 14.5\%, 52 ha per year) and Cottbus $(9.2 \%, 32$ ha per year) followed by Trnava $(7.7 \%, 26$ ha per year).

The second significant overall trend is the increase in the size of other land cover classes, particularly forests and landscape vegetation, water areas and other economically unused land (CLC class $3-5)$. The total average increase in these categories of land use is 1.5\% (114 ha), i.e., 5.2 ha per year. While this trend is not evident in all cities, relatively large differences were observed. A more pronounced increase was recorded for Frankfurt/Oder (6.1\%, 21.7 ha per year), Banská Bystrica $(4.2 \%, 14.9$ ha per year) and Cottbus (3.4\%, 12.2 ha per year). In contrast, Schwerin, and to a lesser extent Ústí nad Labem, recorded a decrease in these areas (Schwerin: 2.3\%, average 8 ha per year), and Trnava, Olomouc and Liberec registered very small changes. 


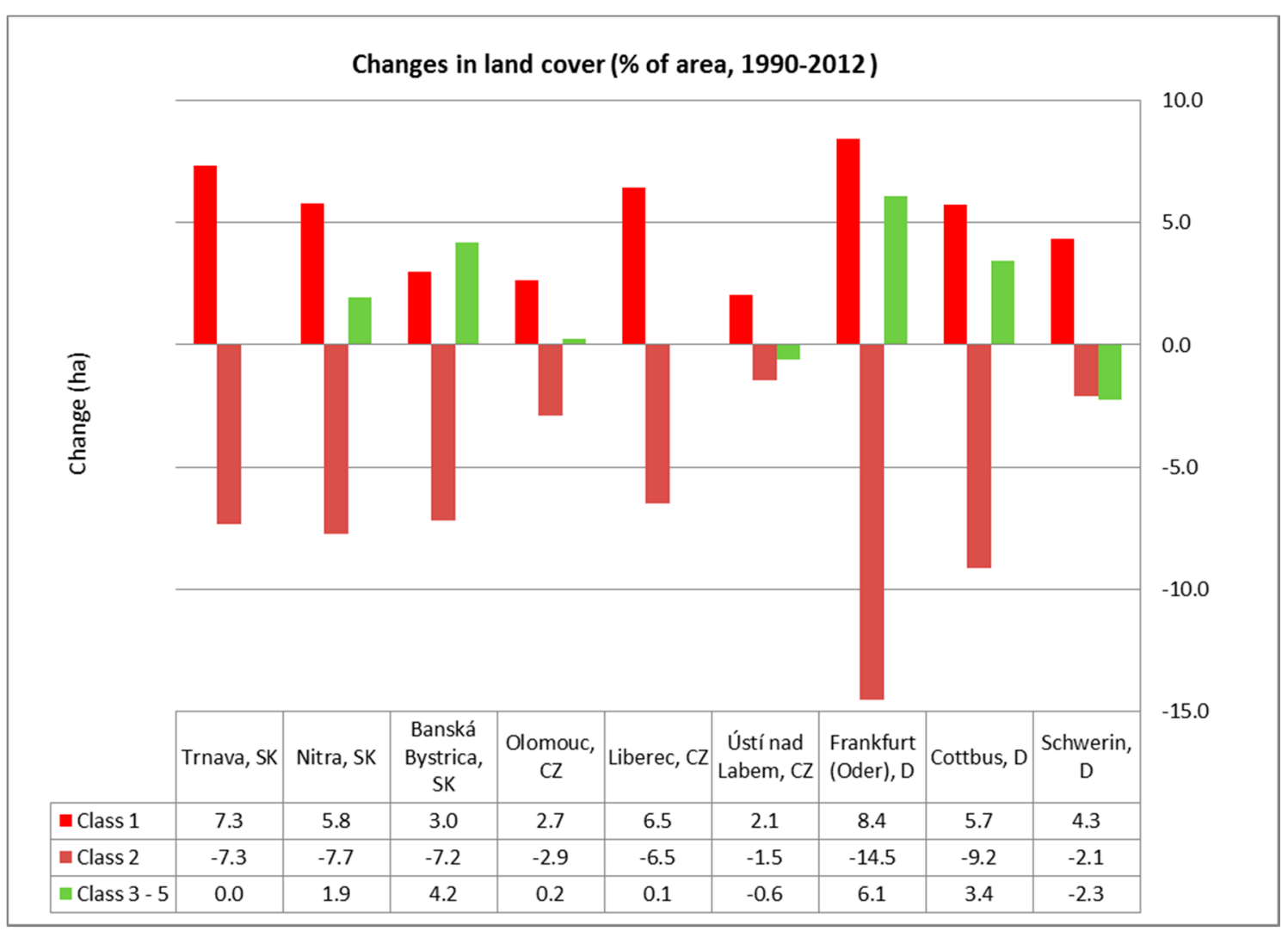

Figure 6. Changes in land cover (1990-2012, \% of area). Class 1, Built-up areas; Class 2, Agricultural land; Classes 3-5, Forests, permanent vegetation, wetlands and water elements, respectively.

Several studies show Central European country land use changes have been very similar since the $1990 \mathrm{~s}[59,78,86]$. There is a permanent decline in agricultural land and increase of built up areas and forests. This is certainly due to suburbanisation or re-urbanisation processes in Western Europe, but it appears delayed in the post-socialist countries. Our assessment of comparable cities in Central Europe confirmed these trends. It is clear, however, that, while the trend of increased built-up areas and decline in agricultural land is pronounced in most of the cities, including Trnava, the changes in forests, water surfaces and unused landscape elements are also affected by other factors. These factors are most likely the natural conditions and the socio-economic development of the area; including population growth. Economic investment and the state of the area prior to 1990 are also surely important. The percentage of these landscape elements is most likely increasing in more geographically complex territories, due, for example, to the abandonment of agricultural land and afforestation (Banská Bystrica [82]) and eventually by recultivation of former mining and technical complexes (Cottbus). In contrast, Trnava is an example of intense agriculturally used area where the percentage of permanent landscape vegetation and forests is still not increasing despite their significant deficit.

\subsubsection{Comparison of Population Development and Accompanying Urbanisation Process}

Changes in population number in the compared cities and the area of housing (CLCs Classes 111 and 112) are shown in Table 4 and Figure 7. 
Table 4. Population and living area in selected cities (1990, 2012).

\begin{tabular}{ccccc}
\hline \multirow{2}{*}{ Cities } & \multicolumn{2}{c}{ Population } & \multicolumn{2}{c}{ Living Area (ha) } \\
\cline { 2 - 5 } & $\mathbf{1 9 9 0}$ & $\mathbf{2 0 1 2}$ & $\mathbf{1 9 9 0}$ & $\mathbf{2 0 1 2}$ \\
\hline Trnava, SK & 71,783 & 66,219 & 1240.9 & 1294.2 \\
Nitra, SK & 89,969 & 78,875 & 2243.9 & 2347.2 \\
Banská Bystrica, SK & 83,400 & 78,327 & 1465.6 & 1622.9 \\
Olomouc, CZ & 105,537 & 101,003 & 1726.8 & 1773.3 \\
Liberec, CZ & 101,967 & 102,247 & 2232.0 & 2339.1 \\
Ústí nad Labem, CZ & 100,002 & 93,000 & 1735.3 & 1661.2 \\
Frankfurt (Oder), D & 84,937 & 59,063 & 1536.3 & 1845.0 \\
Cottbus, D & 123,321 & 99,974 & 3244.1 & 2530.3 \\
Schwerin, D & 124,084 & 95,300 & 1547.4 & 1522.3 \\
\hline \multicolumn{2}{c}{ Source: European and national statistics [61-63]. }
\end{tabular}

Population development in monitored cities is negative in almost all cases, with the number of inhabitants declining. This trend is most pronounced in selected German cities; from 18.9\% (Cottbus) to $30.5 \%$ (Frankfurt/Oder) over the 22-year reviewed period. While population decline in the Slovak towns is significantly lower, from $6.1 \%$ (Banská Bystrica) to $12.3 \%$ (Nitra), the smaller decrease was recorded in selected Czech cities-the largest in Ústí nad Labem (7.0\%). In direct contrast, Liberec documented a slight $(0.3 \%)$ increase in population. While these demographic trends are certainly subject to various factors-administrative changes, different economic and social contexts, etc. - the overall trend of population decrease in Central Europe middle-sized cities is obvious. Trnava with a population decline of $7.8 \%$ is the "average" city in the monitored sample.

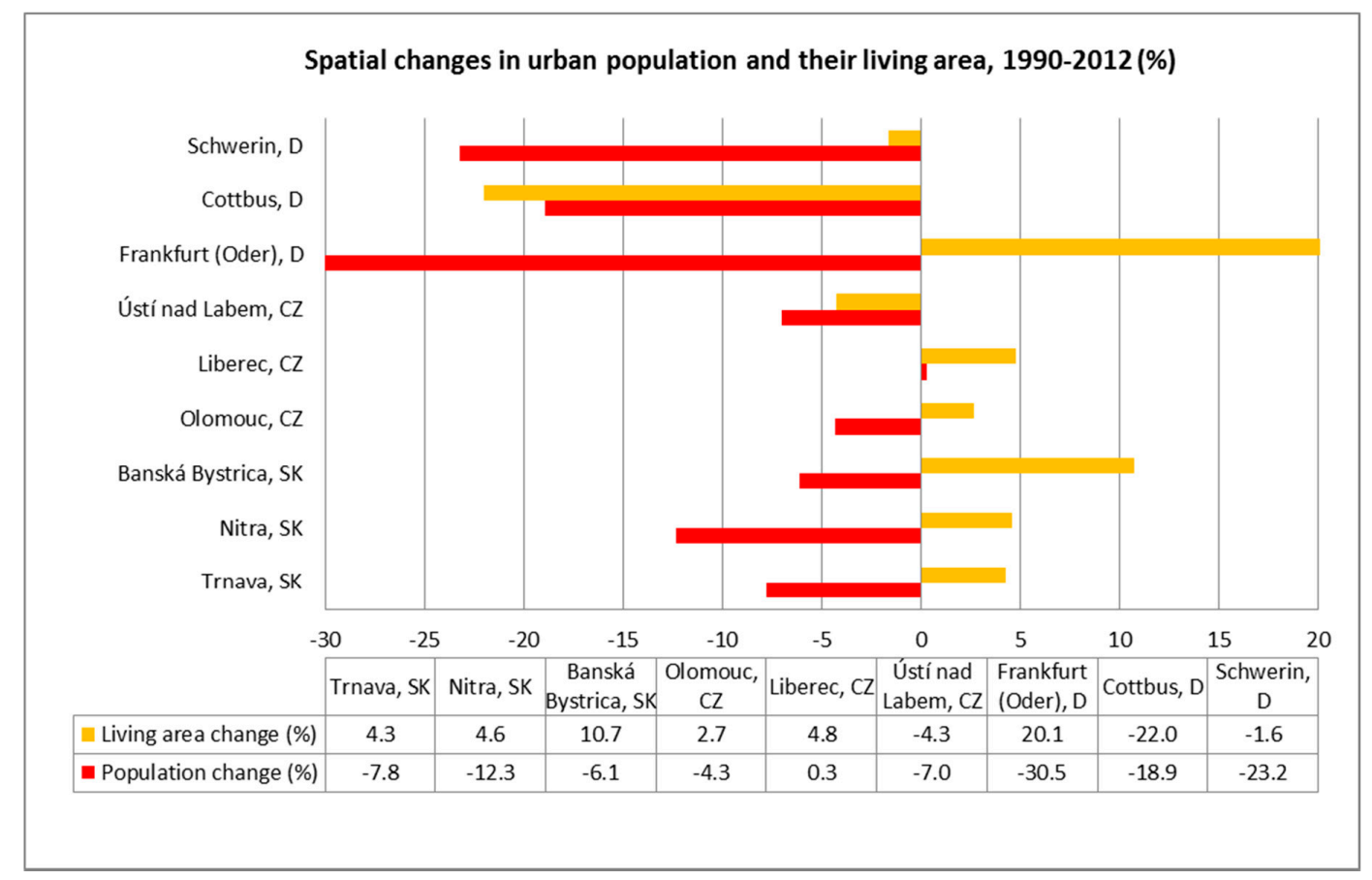

Figure 7. Spatial changes in urban population and their living area (1990 and 2012).

Spatial changes in housing area cannot be described as unambiguous (CLC Classes 111 continuous urban fabric area and 112 discontinuous urban fabric area). In most monitored Slovak and Czech Republic cities, residential areas grew, with the most significantly being Banská Bystrica (10.7\%). In contrast, the Czech Ústí nad Labem recorded a decrease of 4.3\%. In Germany, a significant increase of housing area was recorded in Frankfurt/Oder (20.1\%), while decline was observed in other cities 
( $22 \%$ in Cottbus). These differences, however, may be explained solely by "local" specifics, but these are beyond the scope of our research. However, we conclude from analysing maps of the land cover for 1990 that their accuracy is questionable; thus, these differences, particularly for German cities, are likely due to inaccuracies in the 1990 CLC maps.

It is therefore necessary to take the values of population density changes for 1990-2012 in Figure 8 as merely indicative; we included these in our research to enhance the work of Haase et al. [59]. The 1990 population density in compared cities varied from 38 inhabitants/ha (Cottbus) to 80 inhabitants/ha (Schwerin); in 2012, it was from 32 inhabitants/ha (Frankfur/Oder) to 63 inhabitants/ha (Schwerin). The highest fluctuations were recorded in German cities, and, with the exception of Cottbus, there is an "unrealistic" large drop in population density - $42 \%$ in Frankfurt/Oder).

Population density change values in the selected Slovak and Czech cities are considerably more plausible (Figure 8). While there is decreased population density in all towns, the decrease is smaller in Czech cities (3-7\%) than in Slovak cities (12-16\%). This results from a larger population decrease on the one hand and a larger increase in the living area on the other. Trnava city typically confirms this trend-a $7.8 \%$ decline in population and concomitant $4.3 \%$ rise in residential areas. Hence, population density fell by $12 \%$ over this 22 -year period.

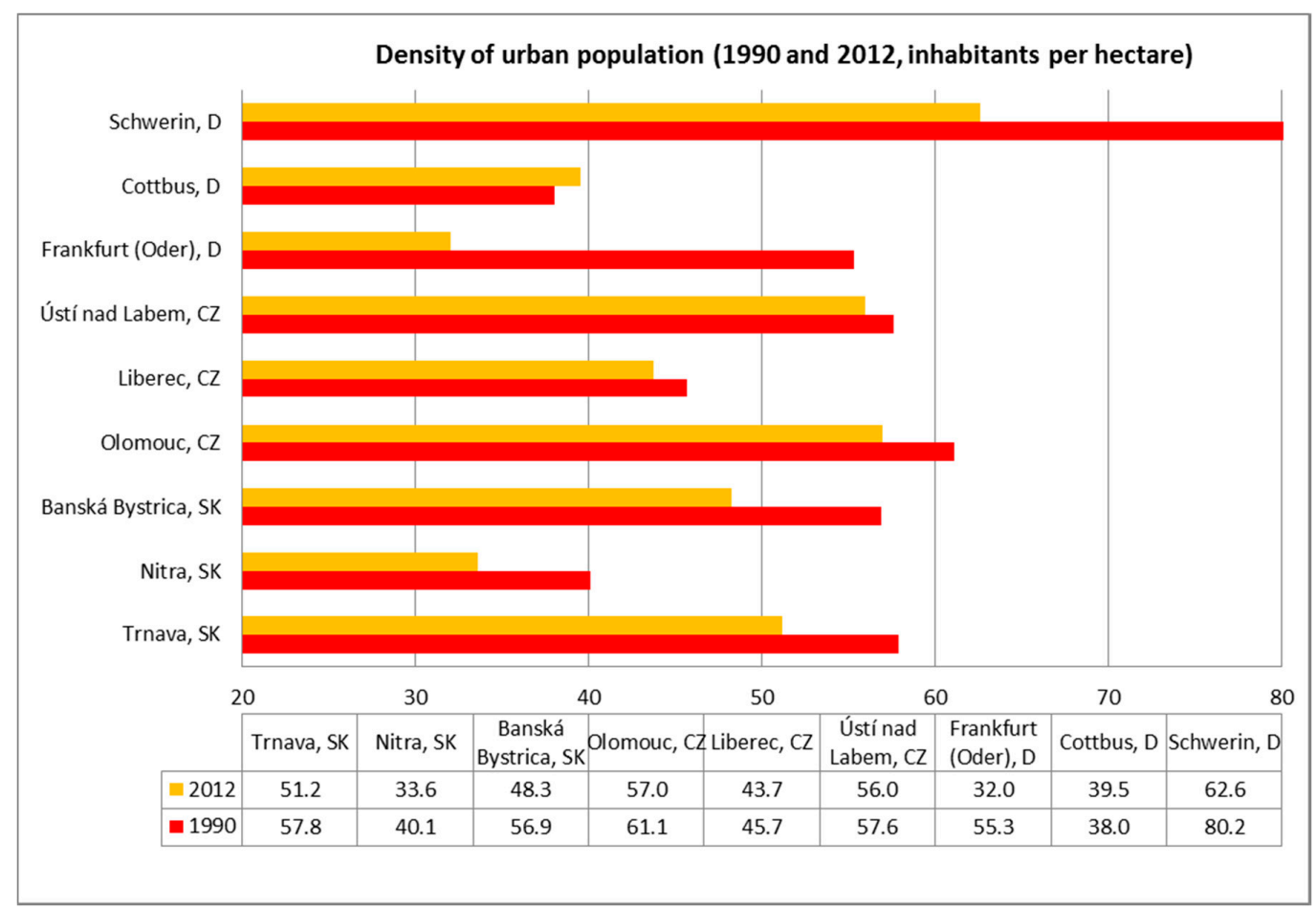

Figure 8. Density of urban population (1990 and 2012).

\section{Discussion}

The presented research results are based on evaluation of land use changes in Trnava city and their comparison with selected cities in Central European countries; in a background of broader trends, related factors and environmental consequences. Most factors and trends are directly or indirectly related to wider understanding of current processes connected with urban development.

\subsection{Broader Context of Socio-Economic Development, Policy and Related Processes in Post-Socialist Cities}

The changes in land use generally reflect different phases of socio-economic development, the political situation and environmental issues in the affected area [6]. In the early 1990s, the urban structure of post-socialist cities shows different composition to Western Europe, with the most 
prominent feature being mass housing estates on a scale unknown in Western European cities [87]. The following factors were significant in shaping socialist cities: (1) poor development of services causing unification of the distribution of inhabitants; (2) collectivisation of land with social, but not economic land value; (3) the morphological structure of new cities and new quarters in old cities; and (4) changes to land-use and organization of the social life of the city inhabitants by large industrial plants [88].

The collapse of communism and later entry of Central/Eastern European countries to the European Union (EU) caused many political, economic and social changes which initiated new trends of land use/land cover changes influencing landscape transition [89]. Political changes triggered new economic interests that greatly affected the cities' structure, and the restitution of private property and democratisation of political life proved significant driving forces in most post-communist countries in the 1990s [31]. The most important general trends in the transition cities are the return of the importance of land rent and the increasing number of participants competing for space, renaissance of self-government, increase in social and spatial differentiation, transformation of employment structures, reshaping townscape and the physical transformation of urban space. The development of urbanisation was also influenced by globalisation, manifested in post communist cities by internationalised investment and labour, deregulation of the public sector force, de-industrialisation, technological changes, community polarisation, sustainable development advocacy and postmodern urban life [33]. These features are obviously copying the European trends in lifestyle change and demand for greater living space $[2,90]$.

Apart from Bratislava, Trnava is the Slovak city with the most pronounced trends in this area. Gradual establishment of market principles in resource allocation and growing exposure to the international economy have been major factors in Trnava urban development [91]. The first decade of transition in the 1990s was characterised by an investment influx in the city centre. Restitution then returned many buildings and a lot of land to the original owners and the real estate market boomed. This was reflected in Trnava's functional structure; with old buildings reconstructed and new residential and service areas built. This was subsequently reflected in improved city centre image. Similar development was also observed in cities in other post-communist countries (Czech Republic, Poland, Hungary and Bulgaria), where original activities were replaced by new ones. These took the form of commercialization [68,92], construction of new apartments [29], brownfield regeneration [93,94] and the establishment of new commercial centres [31,95]. The emergence of brownfields and decline of some housing estates constructed during socialism highlighted major problems remaining in post-socialist cities [96,97].

New economic conditions were also reflected in changes to Trnava's production structure: many enterprises disappeared due to economic non-profitability and brownfields begin to appear. Although some have been gradually revitalised and their structure or use changed, some still exist in previous form and are negatively reflected in the city's scenery.

\subsection{Land Use Changes, Environmental Consequences and Landscape Management after 1990}

Political, social and economic changes in Slovakia and other countries after 1990 have also brought changes in land use, with important environmental consequences. Beyond the boundaries of the continuous urban built-up area forming a "compact city", there has been significant change in the landscape. This comprises emergence of new residential complexes, commercial services, warehouses, industrial parks and logistics centres; often constructed at the city outskirts. The appropriated arable land and the loss of permanent vineyard and orchards are phenomena that have transformed the Slovak suburban landscape and caused irreversible changes. Similar features are also typical for the broader suburbanisation process [53].

The loss of arable land and expansion of urbanised areas are common features of changes in all Central and Eastern European post-socialist countries [6,28,30,59,98-103]. We confirmed this trend in comparative research of all cities although it was less pronounced in some cities due to specific 
development issues (as in Ústí nad Labem [80], Schwerin [85]). The most dramatic changes were recorded for Frankfurt/Oder [104]. The accompanying trend of spatial growth of forests, waters and other economically unused areas was less pronounced, mainly due to the different natural conditions (as in Trnava), and again also due to specific development in the mentioned cities.

However, city land use/land cover structure does not change solely beyond the boundaries of a compact urban built-up area, but also within its borders. Increase in the density of the cities' central areas is obvious-from construction of commercial-administrative centres and residential buildings, and partly due to brownfield reconstruction [105]. This trend has been observed in Trnava and other cities-Liberec [80], Olomouc [28], Banská Bystrica [82] and Nitra [83,84]. The concept of re-greening the cities through nature based solutions and green infrastructure strategies is now emerging to counterbalance these trends $[106,107]$.

With regard to environmental quality, the process of suburbanisation is accompanied not only by a depletion of natural resources (in our case mainly by land-appropriation of agricultural soils) but also by threatening landscape stability, biodiversity and deterioration of the overall quality of the environment. Urban land consumption is normally detrimental to the environment in various ways-its impact reduces nature's ability to meet human requirements, and thus impairs the provision of ecosystem services [108]. The ever-increasing pressure on the natural environment leads to various conflicts of interests, and limits the potential for optimal use of natural capital and ecosystem functions and services [46,109]. Thus, the continuous growth in the size of urban areas and increasing demand on resources and energy pose great challenges in ensuring human welfare in cities, while preventing increasing loss of soil, other resources, habitats and biodiversity [59,87,107].

The anthropisation of Trnava is increasing because of gradual occupancy of agricultural land which subsequently results in reduced landscape ecological stability. Investor pressure is constantly recorded on occupancy of landscape vegetation and urban green areas. The Trnava area is one of the worst regions in Slovakia for spatial ecological stability, with significant deficits of landscape and urban vegetation in both the city area and the entire region. Despite the large city areas of private greenery and sports-grounds, the public green areas and especially the parks are under-sized [45]. A further problem afflicting urban areas is the high number of alien, invasive and introduced species which reduce local ecosystem biological uniqueness. Trnava, for example, has a high percentage of introduced and geographically non-original woods; especially coniferous trees.

Many methods exist for assessment of environmental quality and related problems. Herein, we utilised the conflict of interests [54] and GreenFrame methodologies [55], and the determined spatial relationships confirm dependence of land use and environmental quality in both urban and suburban areas.

Landscape changes of extensive development are currently caused by urbanisation processes; especially urban sprawl and the fragmentation of landscapes by infrastructure development. These have considerable environmental impact, eventually leading to a decline in large continuous habitat patches [79] and changes to farmland structure [78]. However, it is important to recognise the type of changes occurring in recent history and calculate this into future landscape development [78]. These issues may be very site-specific and therefore require specific local solutions in addition to the applied general principles. This knowledge is an essential prerequisite in planning tasks.

\subsection{Planning and Management Responses}

The city administration should respond by reasonable spatial planning and management to all current challenges of spatial development, trends and environmental issues [59,60,77,110-112]. This occurs in many cities, and although also to a certain extent in Trnava, the crucial problem here is implementation of the planning documents in actual practice. Practical steps are often far from declared priorities-mainly due to pressure from asset owners and investors, and this often causes changes in planned and approved activities. This is highlighted in Trnava by 25 amendments made to approved urban plan since 2010—partly at the expense of open spaces and urban green 
areas [84]. Similar problems in planning processes are also encountered in other post-communist countries, where public institutions have weak actual power; planning has lower importance than in many Western European countries and urban development is often driven by developer investment decisions [87].

Planning processes and their implementation in practice must be improved to ensure development sustainability. Slovakia, however, has well-developed landscape-ecological planning for environmental issues, where landscape plans and ecological network documents integrate evaluation of spatial and functional land use and harmonise the landscape-ecological, cultural-historical and socio-economic conditions of the area $[113,114]$. While documents in land consolidation and planning processes are legally binding $[115,116]$, the quality and implementation of such integrated documents are often limited due to their complexity. While this creates greater demand for experts, this is often negated by insufficient allocation of financial resources. In addition, poor understanding and interest in ecological targets in the decision-making sphere are reflected in little willingness to overcome these barriers. Thus, again, the actual implementation of landscape planning in practice is inadequate and needs significant strengthening [113]. This is likely the most common feature in post-communist countries that are struggling with the formality of planning and its detachment from the actual decision-making process.

Landscape-planning processes are normally very complex and large cities, especially, require an integrative approach to natural resource management and consideration of different ecosystem conditions, management priorities and stakeholder interests. There is strong emphasis on sustainable urban development at international and EU levels, with the consideration of main environmental issues and challenges. Such modern planning and management in urban areas could be based, for example, on concepts of "Nature based solutions [107]", "Green Infrastructure" [108] or the widely accepted "Ecosystem services" approach $[77,110,117,118]$. Implementing these concepts in a systematic and holistic manner in landscape-planning processes has the potential to foster integration between the environmental and social and economic aspects of ecosystem utilization [110,117,118], and this could provide a challenge for both Trnava and most European cities.

\section{Conclusions}

Urbanisation is a complex social, economic, political and technological process, and there are no uniform patterns of this process. Further, urbanisation manifests itself primarily in creating urban landscapes with patterns of alternating density, sprawl and shrinkage [59,112,119]. It is also accompanied by subsequent processes including suburbanisation and re-urbanisation [35,36]. Land use changes caused by urbanisation are also reflected as changes in landscape structure and processes, so they are the main root of many environmental problems $[25,120,121]$. Trnava proved a suitable example for our description of the major consequences; and the three main established objects of endangerment were natural resources, landscape habitats and human health.

From these aspects, it is important to engage not only the studies of mapping of land use/land cover structure and related changes, but also to examine the environmental impacts of these changes. Evaluation of the impact of urbanisation on both landscape and environment require new methods and new approaches that consider not only the complexity of urbanisation dynamics, but also interdependencies between drivers, impacts, and responses to these dynamics [111]. There is a growing research agenda in these issues, but, in many aspects, it is just beginning, and still unbounded by theory or a set of frameworks [112,122-124]. Interdisciplinarity is an essential approach to the study of urban development [125-127] because people live in cities and their behaviour and decisions influence all processes in the urban environment. Furthermore, residents can accept the measures required to protect the values of urban nature only if they understand it [128].

The integration of natural, social and economic sciences is an indispensable approach for a holistic view of the urban environment-but generally accepted integrated approaches are not enough when applied in actual practice. Better balanced and sustainably developed urban growth and shrinkage also 
requires more policy attention given to urban-rural linkages at the regional level, although there is also a clear need for a new agenda respecting EU policies and funds linked to spatial development. The time has come in policy making to challenge the historic distinction between urban and rural issues, and this necessitates a more holistic, territorially-oriented perspective designed to shape future EU urban, agricultural and structural policies [90]. Such research also has an important role in supporting sustainable urban-rural relationships, and should focus on gaining new knowledge and developing new methods to improve efficient management, use and conservation of natural resources.

Our study focuses on evaluation of land use changes in the city of Trnava, their impacts on the environment and important socio-economic contexts. It also offers comparison with several similar post-socialist cities and also the future outlook based on an approved urban development plan. Our research also highlights some negative consequences of current development and future risks, including lagging behind modern European research and planning trends; especially ecosystem services, green infrastructure and nature based solutions. The results of the research and outlined recommendations are directed towards gradual application of these progressive methods in research and planning of urban development and landscape management, especially in the conditions of post-socialist countries.

Acknowledgments: This research was funded by the Ministry of Education of the Slovak Republic (No. 1/0496/16 "Assessment of natural capital, biodiversity and ecosystem services in Slovakia") and from the Slovak Research and Development Agency (No. APVV-0866-12 "Evaluation of ecosystem functions and services of the cultural landscape"). We are grateful to Peter Bezák and Juraj Lieskovský for their significant inputs to the application of the GreenFrame method for Trnava, and to Raymond Marshall for proofreading the manuscript.

Author Contributions: Zita Izakovičová compiled the methodology and theoretical context of work and wrote the majority of the discussion and conclusion. Peter Mederly contributed to the methodology, compilation of the results and their interpretation in the discussion and conclusion. František Petrovič contributed to the evaluation of the land use maps, analyses of land use changes and comparison of cities.

Conflicts of Interest: The authors declare no conflict of interest.

\section{References}

1. European Environmental Agency (EEA). The European Environment State and Outlook 2015. Assessment of Global Megatrends; European Environmental Agency: Copenhagen, Denmark, 2015.

2. European Environmental Agency (EEA). The European Environment-State and Outlook 2010: Synthesis; European Environmental Agency: Copenhagen, Denmark, 2010.

3. Vokoun, J. Megatrends-Effects of Changes in Demographical Development and Urbanisation in Slovakia; Ekonomický ústav SAV: Bratislava, Slovakia, 2006. (In Slovak)

4. Miklós, L.; Izakovičová, Z. Landscape as Geosystem; Veda: Bratislava, Slovakia, 1997. (In Slovak)

5. Žigrai, F. Integrated approach to the research of the cultural landscape. In Landscape-Men-Culture; Slovak Environmental Agency: Banská Bystrica, Slovakia, 2001; pp. 16-22.

6. Bičík, I.; Jeleček, L.; Štěpánek, V. Land-Use changes and their social driving forces in Czechia in the 19th and 20th centuries. Land Use Policy 2001, 18, 65-73. [CrossRef]

7. Peck, J.; Tickell, A. Neoliberalizing space. In Spaces of Neoliberalism: Urban Restructuring in North America and Western Europe; Brenner, N., Theodore, N., Eds.; John Wiley \& Sons: Malden, UK; Oxford, UK; Victoria, UK, 2002; pp. 33-57.

8. Šuška, P. Production of the built environment in the postsocialist city of Bratislava: Conditions, dynamics, and spatial manifestation (in Slovak). Geogr. Časopis Geogr. J. 2012, 64, 155-179.

9. Tasan-Kok, T. Global urban forms and local strategies of property market actors. J. Hous. Built Environ. 2007, 22, 69-90. [CrossRef]

10. Mendel, M. Residential developers and investors in central Europe: Boom and bust. Monu Mag. Urban. 2010, 12, 23-30.

11. Dyer, J.M. Land use pattern, forest migration and global warming. Landsc. Urban Plan. 1994, 29, 77-83. [CrossRef]

12. White, M.A.; Mladenoff, D.J. Old-growth forest landscape transition from pre-European settlements to present. Landsc. Ecol. 1994, 9, 101-205. [CrossRef] 
13. Poudevigne, I.; Alard, D. Agricultural landscape dynamic: A case study in the Odessa region, the Ukraine and comparative analysis with the Brionne basin case study, France. Ekológia (Bratislava) 1997, 16, $295-308$.

14. Skanes, H.M.; Bunce, R.G.H. Direction of landscape changes (1741-1993) in Virestaad Sweden-Characterise by multivariate analysis. Landsc. Urban Plan. 1997, 38, 61-75. [CrossRef]

15. Lipský, Z. Investigation of Changes in Cultural Landscapes; Czech Agricultural University: Praha, Czech Republic, 2000. (In Czech)

16. Feranec, J.; Ot'ahel', J. Maping of the land land cover by method CORINE, proposal of the legend for PHARE countries. Geogr. Časopis Geogr. J. 1999, 51, 19-44.

17. Yafei, L.; Gaohuan, L. Characterizing spatiotemporal pattern of land use change and its driving force based on GIS and landscape analysis techniques in Tianjin during 2000-2015. Sustainability 2017, 9, 894. [CrossRef]

18. Gellrich, M.; Baur, P.; Koch, B.; Zimmermann, N.E. Agricultural land abandonment and natural forest re-growth in the Swiss mountains: A spatially explicit economic analysis. Agric. Ecosyst. Environ. 2007, 118, 93-108. [CrossRef]

19. Kuemmerle, T.; Hostert, P.; Radeloff, V.C.; Perzanowski, K.; Kruhlov, I. Postsocialist forest disturbance in the Carpathian border region of Poland, Slovakia, and Ukraine. Ecol. Appl. 2007, 17, 1279-1295. [CrossRef] [PubMed]

20. Tasser, E.; Walde, J.; Tappeiner, U.; Teutsch, A.; Noggler, W. Land-use changes and natural reforestation in the Eastern Central Alps. Agric. Ecosyst. Environ. 2007, 118, 115-129. [CrossRef]

21. Müller, D.; Kuemmerle, T.; Rusu, M.; Griffiths, P. Lost in transition: Determinants of post-socialist cropland abandonment in Romania. J. Land Use Sci. 2009, 4, 109-129. [CrossRef]

22. Munteanu, C.; Kuemmerle, T.; Boltiziar, M.; Butsic, V.; Gimmi, U.; Kaim, D.; Király, G.; Konkoly-Gyuró, É.; Kozak, J.; Lieskovský, J.; et al. Forest and agricultural land change in the Carpathian region-A meta-analysis of long-term patterns and drivers of change. Land Use Policy 2014, 38, 685-697. [CrossRef]

23. Fei, Z.H.; Johnson, C.V. Assessment of land-cover/land-use change and landscape patterns in the two national nature reserves of Ebinur Lake Watershed, Xinjiang, China. Sustainability 2017, 9, 724. [CrossRef]

24. Torre, M.C.; Morano, P.; Tajani, F. Saving Soil for Sustainable Land Use. Sustainability 2017, 9, 350. [CrossRef]

25. Petrovič, F. Changes of the landscape with dispersed settlement. Ekológia (Bratislava) 2006, 25, $201-211$.

26. Opršal, Z.; Kladivo, P.; Machar, I. The role of selected biophysical factors in long-term land-use change of cultural landscape. Appl. Ecol. Environ. Res. 2016, 14, 23-40. [CrossRef]

27. Simpson, F. Tourist impact in the historic centre of Prague: Resident and visitor perceptions of the historic built environment. Geogr. J. 1999, 165, 173-183. [CrossRef]

28. Václavík, T.; Rogan, J. Identifying Trends in Land Use/Land Cover Changes in the Context of Post-Socialist Transformation in Central Europe: A Case Study of the Greater Olomouc Region, Czech Republic. GISci. Remote Sens. 2006, 46, 54-76. [CrossRef]

29. Medvedkov, Y.; Medvedkov, O. Upscale housing in post-Soviet Moscow and its environs. In The Post-Socialist City: Urban Form and Space Transformations in Central and Eastern Europe after Socialism; Stanilov, K., Ed.; Springer: Dordrecht, The Netherlands, 2007; pp. 245-265.

30. Łowicki, D. Land use changes in Poland during transformation. Case study of Wielkopolska region. Landsc. Urban Plan. 2008, 87, 279-288. [CrossRef]

31. Sýkora, L.; Bouzarowski, S. Multiple Transformations: Conceptualising the Post-communist Urban Transition. Urban Stud. 2011, 49, 1-18. [CrossRef]

32. Leško, L. Comparison of Eastern and Western Europe Spatial Development of Cities Based on Remote Sensing Data. Master's Thesis, Eberswalde University for Sustainable Development-HNEE Applied University, Eberswalde, Germany, 2013.

33. Matlovič, R. Transformation processes and their effects in intra-urban structures of post-communist cities. In Acta Facultatis Rerum Naturalium Universitatis Matthiae Belii, Geografické štúdie; UMB: Banská Bystrica, Slovakia, 2001; pp. 73-81. (In Slovak)

34. Kladivo, P.; Roubínek, P.; Opravil, Z.; Nesvadbová, Z. Suburbanization and local governance-Positive and negative forms: Olomouc case study. Bull. Geogr. 2015, 27, 95-107. [CrossRef]

35. Matlovič, R.; Sedláková, A. The impact of suburbanisation in the Hinterland of Prešov (Slovakia). Morav. Geogr. Rep. 2007, 15, 22-31.

36. Ouředníček, M.; Šimon, M.; Kopečná, M. The reurbanisation concept and its utility for contemporary research on post-socialist cities: The case of the Czech Republic. Morav. Geogr. Rep. 2015, 23, 26-35. [CrossRef] 
37. Kopecká, M.; Rosina, K. Identification of changes in urbanized landscape based on VHR satellite data: Study area of Trnava (in Slovak). Geogr. Časopis Geogr. J. 2014, 66, 247-267.

38. Šveda, M.; Vigašová, D. Land use changes in the hinterland of major Slovak cities. Geografie 2010, 115, 413-439. (In Slovak)

39. Quattrochi, D.A.; Pelletier, R.E. Remote Sensing for Analysis of Landscapes: An Introduction. In Quantitative Methods in Landscape Ecology. The Analysis and Interpretation of Landscape Heterogeneity, Ecological Studies; Turner, M.G., Gardner, R.H., Eds.; Springer: New York, NY, USA, 1991; Volume 82, pp. 51-76.

40. Kienast, F. Analysis of historic landscape patterns with a geographical information system-A methodological outline. Landsc. Ecol. 1993, 8, 103-118. [CrossRef]

41. Mander, Ü.; Murka, M. Landscape coherence: A new criterion for evaluating impacts of land use changes. In Multifunctional Landscapes. Vol. III-Continuity and Change; Mander, Ü., Antrop, M., Eds.; WIT Press: Southampton, UK, 2003; pp. 15-32.

42. Pauleit, S.; Ennos, R.; Golding, Y. Modelling the environmental impacts of urban land use and land cover change-A study in Merseyside, UK. Landsc. Urban Plan. 2005, 71, 295-310. [CrossRef]

43. Palang, H.; Helmfrid, S.; Antrop, M.; Alumae, H. Rural landscapes: Past processes and future strategie. Landsc. Urban Plan. 2005, 70, 3-8. [CrossRef]

44. National Geoportal of the Slovak Republic. Available online: http://geoportal.gov.sk/sk/cat-client?r= geoportal.sazp.sk (accessed on 30 July 2017).

45. Dobrucká, M. Territorial System of Ecological Stability of Trnava Town-Actualisation; Atelier Dobrucka Ltd.: Nitra, Slovakia, 2009. (In Slovak)

46. Mederly, P.; Izakovičová, Z.; Bezák, P. Operationalization of natural capital and ecosystem services-from concept to real-world applications. In Environmental Indices, Agro-Environmental Measures and Ecosystem Services in Landscape; Klikušovská, Z., Sviček, M., Eds.; VÚPOP: Bratislava, Slovakia, 2013; pp. 135-138. (In Slovak)

47. Zibrin, P. Urban Plan of the Trnava City-Actualized Version 2009; Ekopolis Ltd.: Trnava, Slovakia, 2009. (In Slovak)

48. Čurlík, J.; Šefčík, P. Geochemical Atlas of Soils in Slovakia; SGÚŠ, MŽP SR: Bratislava, Slovakia, 1999. (In Slovak)

49. Enviroportal of the Slovak Republic. Available online: https://www.enviroportal.sk/ (accessed on 30 July 2017).

50. Soil Portal of the Slovak Republic. Available online: http://www.podnemapy.sk/default.aspx (accessed on 30 July 2017).

51. Izakovičová, Z.; Hrnčiarová, T.; Moyzeová, M. Ecologization of the Economy in the Parna Watershed: Local Agenda 21; Združenie Krajina 21: Bratislava, Slovakia, 2001; p. 185. (In Slovak)

52. Moyzeová, M. Quality of Environment Assessment for Rural Settlements (Example of Trnava District); ÚKE SAV: Bratislava, Slovakia, 2015; p. 280. (In Slovak)

53. Kopecká, M.; Rosina, K.; Ot’ahel, J.; Feranec, J.; Pazúr, R.; Nováček, J. Monitoring of development dynamics on local level (Study area of Trnava). In Geographia Slovaca 30; Institute of Geography SAS: Bratislava, Slovakia, 2015. (In Slovak)

54. Izakovičová, Z.; Moyzeová, M. Environmental evaluation of the impact of human activities in the landscape. Gospod. Surowcami Miner. 2008, 24, 154-158.

55. Kopperoinen, L.; Itkonen, P.; Niemela, J. Using expert knowledge in combining green infrastructure and ecosystem services in land use planning: An insight into a new place-based methodology. Landsc. Ecol. 2014, 29, 1361-1375. [CrossRef]

56. Izakovičová, Z.; Oszlányi, J. The landscape of Slovakia, its nature and transformations. In Lost Landscapes: Reflections from Central European Border Regions; Csaplovics, E., Ed.; Regional Development Agency Mura Ltd.: Murska Sobota, Slovenia, 2012; pp. 115-131.

57. Miklós, L. Landscape stability in Ecological generel of Slovakia (in Slovak). In Životné Prostredie; ÚKE SAV: Bratislava, Slovakia, 1986; Volume 20, pp. 87-93.

58. Izakovičová, Z.; Miklós, L.; Moyzeová, M. Model of the Representative Geoecosystems at Regional Level, 1st ed.; Institute of Landscape Ecology of SAS: Bratislava, Slovakia, 2011. (In Slovak)

59. Haase, D.; Kabisch, N.; Haase, A. Endless urban growth? On the mismatch of population, household and urban land area growth and its effects on the urban debate. PLoS ONE 2013, 8, e66531. [CrossRef] [PubMed] 
60. Mederly, P.; Bezák, P.; Izakovičová, Z. Ecosystem services assessment methods-Examples and perspectives for planning and decision making. In Flows, Spaces and Societies in Central Europe, Abstract Book from 11th Slovak-Czech-Polish Seminarium, 2017; Comenius University: Bratislava, Slovakia, 2017; p. 62.

61. Cities (Urban Audit). Available online: http:/ / ec.europa.eu/eurostat/web/cities/data/database (accessed on 30 July 2017).

62. DATAcube. Demography and Housing in the Slovak Republic. Available online: http:/ / datacube.statistics. sk/SODB/TM1WebLogin.aspx (accessed on 30 July 2017).

63. MOS-Municipality Statistics. Available online: https://vdb.czso.cz/mos/ (accessed on 30 July 2017).

64. Corine Land Cover. Available online: http://land.copernicus.eu/pan-european/corine-land-cover (accessed on 30 July 2017).

65. Trnava-Basic Information. Available online: http:/ / www.trnava.sk/en (accessed on 30 July 2017).

66. Izakovičová, Z. Ecological factors of the sustainable development of the settlements (in Slovak). Životné Prostr. 1994, 28, 306-308.

67. Izakovičová, Z.; Oszlányi, J. The impact of stress factors, landscape loads and human activities: Implications for sustainable development. Int. J. Environ. Waste Manag. 2013, 11, 111-128. [CrossRef]

68. Sýkora, L. Changes in the internal spatial structure of post-communist Prague. GeoJournal 1999, 49, 79-89. [CrossRef]

69. Pucher, J. The Transformation of urban transport in the Czech Republic, 1988-1998. Transp. Policy 1994, 6, 225-236. [CrossRef]

70. Hirt, S.; Kovachev, A. The changing spatial structure of post-socialist Sofia. In The Urban Mosaic of Post-Socialist Europe: Space, Institutions and Policy; Tsenkova, S., Nedovic-Budic, Z., Eds.; Physica-Verlag Rudolf Liebing: Heidelberg, Germany, 2006; pp. 113-130.

71. Kotus, J. Changes in the spatial structure of a large Polish city-The case of Poznań. Cities 2006, 23, 364-381. [CrossRef]

72. Bouzarovski, S. Post-socialist energy reforms in critical perspective: Entangled boundaries, scales and trajectories of change. Eur. Urban Reg. Stud. 2010, 17, 167-182. [CrossRef]

73. Stanners, D.; Bourdeau, P. Europe's Environment. The Dobris Assesment; Europaean Environment Agency: Copenhagen, Denmark, 1995; 676p.

74. Izakovičová, Z. Integrated Landscape Management II; ILE SAS: Bratislava, Slovakia, 2006; p. 232. (In Slovak)

75. Haase, D.; Haase, A.; Kabisch, N.; Kabisch, S.; Rink, D. Actors and factors in land-use simulation: The challenge of urban shrinkage. Environ. Model. Softw. 2012, 35, 92-103. [CrossRef]

76. Bleha, B. Local population development in Slovakia: Perception, social implications and interdisciplinary prospects. Sociologia 2011, 43, 362-390.

77. Bezák, P.; Mederly, P.; Izakovičová, Z.; Špulerová, J.; Schleyer, C. Divergence and conflicts in landscape planning across spatial scales in Slovakia: Opportunity for an ecosystem services-based approach? Int. J. Biodivers. Sci. Ecosyst. Serv. Manag. 2017, 13, 119-135. [CrossRef]

78. Haase, D.; Walz, U.; Neubert, M.; Rosenberg, M. Changes to Central European landscapes-Analysing historical maps to approach current environmental issues, examples from Saxony, Central Germany. Land Use Policy 2007, 24, 248-263. [CrossRef]

79. Kuhn, I.; Brandl, R.; Klotz, S. The flora of German cities is naturally species rich. Evol. Ecol. Res. 2004, 6, 749-764.

80. Nevěděl, L.; Pařil, J. Population growth in the hinterland of regional town-centers in Czech Republic in 2001-2011. In Proceedings of the XVII. Intern. Colloquium of Regional Sciences, Hustopeče, Czech Republic, 18-20 June 2014; pp. 669-676. (In Czech)

81. Hájek, V.; Nižnanský, B.; Popková, K. The Use of Old Plans in Studying the Current Area of Liberec: Hus-Street in the Space and Time; Technical University in Liberec: Liberec, Czech Republic, 2012. (In Czech)

82. Vigašová, D.; Papajová-Majeská, L'.; Krížová, L.; Šveda, M. Land use changes in the suburban zones of Banská Bystrica and Zvolen (Slovakia). Morav. Geogr. Rep. 2010, 18, 43-52.

83. Repaská, G.; Vilinová, K.; Šolcová, 1. Trends in Development of residential areas in Suburban Zone of the City of Nitra (Slovakia). Eur. Countrys. 2017, 9, 287-301. [CrossRef]

84. Haladová, I.; Petrovič, F. Predicted Development of the city of Nitra based on land cover-land use changes and Socio-economic conditions. Appl. Ecol. Environ. Res. 2017, (in press). 
85. Albrecht, W.; Weber, E. The development and function, structure and population of the towns of Rostock, Schwerin and Neubrandenburg (in German). Z. Wirtsch. 1991, 35, 106-122.

86. Bański, J. The consequences of changes of ownership for agricultural land use in Central European countries following the collapse of the Eastern Bloc. Land Use Policy 2017, 66, 120-130. [CrossRef]

87. Haase, D.; Piorr, A.; Schwarz, N.; Rickebusch, S.; Kroll, F.; van Delden, H.; Zuin, A.; Taylor, T.; Boeri, M.; Zasada, I. Tools for modelling and assessing peri-urban land use futures. In Peri-Urban Futures; Scenarios and Models for Land Use Change in Europe; Nilsson, K., Pauleit, S., Bell, S., Aalbers, C., Nielsen, T.A.S., Eds.; Springer: Heidelberg, Germany, 2013; pp. 69-90.

88. Liszewski, S. 2000: Pilgrimages or Religious Tourism? Peregrinus Cracoviensis; Instytut Geografii Uniwersytetu Jagielońskiego: Krakow, Poland, 2000; pp. 47-51.

89. Kupková, L.; Bičík, I. Landscape transition after the collapse of communism in Czechia. J. Maps 2016, 12, 526-531. [CrossRef]

90. Nilsson, K.; Nielsen, T.S.; Aalbers, K.; Bell, S.; Boitier, B.; Chery, J.P.; Fertner, C.; Groschowski, M.; Haase, D.; Loibl, W. Strategies for sustainable urban development and urban-rural linkages. Eur. J. Spat. Dev. 2014, 3, 1-26.

91. Ira, V. The changing intra-urban structure of the Bratislava city and its perception. Geogr. Časopis Geogr. J. 2003, 55, 91-107.

92. Hirt, S. Landscapes of post-modernity: Changes in the built fabric of Belgrade and Sofia since the end of socialism. Urban Geogr. 2008, 29, 785-809. [CrossRef]

93. Feldman, M. Urban waterfront regeneration and local governance in Tallinn. Eur. Asia Stud. 2000, 52, 829-850. [CrossRef]

94. Kiss, E. Spatial impacts of post-socialist industrial transformation in the major Hungarian cities. Eur. Urban Reg. Stud. 2004, 11, 81-87. [CrossRef]

95. Temelová, J.; Novák, J. From industrial neighbourhood to modern urban centre: Transformation in physical and functional environment of central Smíchov. Geogr. Sb. CGS 2007, 112, 315-333.

96. Maier, K. Czech housing estates: Recent changes and challenges. Geogr. Pol. 2005, 78, 39-51.

97. Sýkora, L. Gentrification in post-communist cities. In The New Urban Colonialism: Gentrification in a Global Context; Atkinson, R., Bridge, G., Eds.; Routledge: London, UK, 2005; pp. 90-105.

98. Spilková, J.; Šefrna, L. Uncoordinated new retail development and its impact on land use and soils: A pilot study on the urban fringe of Prague, Czech Republic. Landsc. Urban Plan. 2010, 94, 141-148. [CrossRef]

99. Skokanová, H.; Havlíček, M.; Borovec, R.; Demek, J.; Eremiášová, R.; Chrudina, Z.; Mackovčin, P.; Rysková, R.; Slavík, P.; Stránská, T. Development of land use and main land use change processes in the period 1836-2006: Case study in the Czech Republic. J. Maps 2012, 8, 88-96. [CrossRef]

100. Tarasovičová, Z.; Saksa, M.; Blažík, T.; Falt’an, V. Changes in agricultural land use in the context of ongoing transformational processes in Slovakia. Agriculture 2013, 59, 49-64. [CrossRef]

101. Kopecká, M.; Vatseva, R.; Feranec, J.; Ot'ahel, J.; Rosina, K. Urban land cover changes: Case studies Trnava (Slovakia) and Burgas (Bulgaria). In Land Use Changes in Selected Regions in the World; Bičík, I., Himiyama, Y., Eds.; Faculty of Science, Charles University in Prague and Hokkaido University of Education: Asahikawa, Japan, 2014; pp. 49-55.

102. Gerard, F.; Petit, S.; Smith, G.; Thomson, A.; Brown, N.; Manchester, S.; Wadsworth, R.; Bugár, G.; Halada, L.; Bezak, P.; et al. Land cover change in Europe between 1950 and 2000 determined employing aerial photography. Prog. Phys. Geogr. 2010, 34, 183-205. [CrossRef]

103. Wustemann, H.; Kalisch, D.; Kolbe, J. Access to urban green space and environmental inequalities in Germany. Landsc. Urban Plan. 2017, 164, 124-131. [CrossRef]

104. Schene, U.; Torronen, J.; Roura, A.C.; Ferrando, D.V.; Hyytiainen, R.; Myllynen, T. Border Landscape across Europe. Landscape Change across the Border. Frankfurt (Oder)—Slubice; EU Lifelong learning programme, Adam Mickiewicz University: Poznan, Poland, 2014.

105. Feranec, J.; Kopecká, M.; Ot’ahel, J.; Nováček, J. Spreading the build-up area in Slovakia in 2000-2006. Geogr. Cassoviensis, 2010, 4, 13-21. (In Slovak)

106. Maes, J.; Jacobs, S. Nature best solutions for Europe's Sustainable Development. Conserv. Lett. 2017, 10, 121-124. [CrossRef] 
107. Maes, J.; Barbosa, A.; Baranzelli, C.; Zulian, G.; Batista e Silva, F.; Vandecasteele, I.; Hiederer, R.; Liquete, C.; Paracchini, M.L.; Mubareka, S. More green infrastructure is required to maintain ecosystem services under current trends in land-use change in Europe. Landsc. Ecol. 2015, 30, 517-534. [CrossRef] [PubMed]

108. Nuissl, H.; Haase, D.; Wittmer, H.; Lanzendorf, M. Environmental impact assessment of urban land use transitions-A context-sensitive approach. Land Use Policy 2009, 26, 414-424. [CrossRef]

109. Grunewald, K.; Bastian, O. Ecosystem Services. Concept, Methods and Case Studies; Springer: Berlin, Germany, 2015; p. 312.

110. Albert, C.; Aronson, J.; Fürst, C.; Opdam, P. Integrating ecosystem services in landscape planning: Requirements, approaches, and impacts. Landsc. Ecol. 2014, 29, 1277-1285. [CrossRef]

111. Haase, D.; Frantzeskaki, N.; Elmqvist, T. Ecosystem services in urban landscape. Practical applications and governance implications. Ambio 2014, 43, 407-412. [CrossRef] [PubMed]

112. Elmqvist, T.; Fragkias, M.; Goodness, J.; Güneralp, B.; Marcotullio, P.J.; McDonald, R.I.; Parnell, S.; Schewenius, M.; Sendstad, M.; Seto, K.C. Urbanization, Biodiversity and Ecosystem Services: Challenges and Opportunities. A Global Assessment; Springer: Dordrecht, The Netherlands, 2013; p. 755.

113. Izakovičová, Z. Ecological interpretations and evaluation of encounters of interests in landscape. Ekológia (Bratislava) 1995, 14, 261-275.

114. Miklós, L. The concept of the territorial system of ecological stability in Slovakia. In Ecological and Landscape Consequences of Land Use Change in Europe. Man and Nature 2; Jongman, R.H.G., Ed.; European Centre for Nature Conservation: Tilburg, The Netherlands, 1996; pp. 385-406.

115. Moyzeová, M.; Kenderessy, P. Territorial systems of ecological stability in land consolidation projects (Example of proposal for the LSES of Klasov village, Slovak Republic). Ekológia (Bratislava) 2015, 34, 356-370. [CrossRef]

116. Muchová, Z.; Jusková, K. Stakeholders' perception of defragmentation of new plots in a land consolidation project: Given the surprisingly different Slovak and Czech approaches. Land Use Policy 2017, 66, 356-363. [CrossRef]

117. Hauck, J.; Görg, C.; Varjopuro, R.; Ratamäki, O.; Maes, J.; Wittmer, H.; Jax, K. Maps have an air of authority: Potential benefits and challenges of ecosystem service maps at different levels of decision making. Ecosyst. Serv. 2013, 4, 25-32. [CrossRef]

118. Jacobs, S.; Dendoncker, N.; Martín-López, B.; Barton, D.N.; Gomez-Baggethun, E.; Boeraeve, F.; McGrath, F.L.; Vierikko, K.; Geneletti, D.; Sevecke, K.J. A new valuation school: Integrating diverse values of nature in resource and land use decisions. Ecosyst. Serv. 2016, 22, 213-220. [CrossRef]

119. Weber, C.; Puissant, A. Urbanization pressure and modelling of urban growth: Example of the Tunis Metropolitan Area. Remote Sens. Environ. 2003, 86, 341-352. [CrossRef]

120. Forman, R.T.T.; Godron, M. Landscape Ecology; John Wiley and Sons: New York, NY, USA, 1986; p. 619.

121. Olah, B.; Boltižiar, M.; Petrovič, F. Land use change's relation to geeoelief and distance in the East Carpathiaas Biosphere Reserve. Ekológia (Bratislava) 2006, 25, 68-81.

122. Cadenasso, M.L.; Pickett, S.T.; Groffman, P.M.; Band, L.E.; Brush, G.S.; Galvin, M.F.; Grove, J.M.; Hagar, G.; Marshall, V.; McGrath, B.P. Exchanges across land-water-scape boundaries in urban systems: Strategies for reducing nitrate pollution. Ann. N. Y. Acad. Sci. 2008, 1134, 213-232. [CrossRef] [PubMed]

123. Jepsen, M.R.; Kuemmerle, T.; Müller, D.; Erb, K.; Verburg, P.H.; Haberl, H.; Vesterager, J.P.; Andrič, M.; Antrop, M.; Austrheim, G. Transitions in European land-management regimes between 1800 and 2010. Land Use Policy 2015, 49, 53-64. [CrossRef]

124. Kraemer, R.; Prishchepov, A.V.; Müller, D.; Kuemmerle, T.; Radeloff, V.C.; Dara, A.; Terekhov, A.; Frühauf, M. Long-term agricultural land-cover change and potential for cropland expansion in the former Virgin Lands area of Kazakhstan. Environ. Res. Lett. 2015, 10, 054012. [CrossRef]

125. Niemelä, J. Ecology in urban planning. Biodivers. Conserv. 1999, 8, 119-131. [CrossRef] 
126. Konijnendijk, C.C.; Ricard, R.M.; Kenney, A.; Randrup, T.B. Defining urban forestry-A comparative perspective of North America and Europe. Urban For. Urban Green. 2006, 4, 93-103. [CrossRef]

127. McIntyre, N.E. Ecology of urban arthropods: A review and a call to action. Ann. Entomol. Soc. Am. 2000, 93, 825-835. [CrossRef]

128. Breuste, J.H. Decision making, planning and design for the conservation of indigenous vegetation within urban development. Landsc. Urban Plan. 2004, 68, 439-452. [CrossRef]

(c) (1) 